\title{
Secretory Protein Traffic Chromogranin A Contains a Dominant Targeting Signal for the Regulated Pathway
}

Robert J. Parmer, Xiao-Ping Xi, Hong-Jiang Wu, Lee J. Helman, * and Larry N. Petz

Department of Medicine, University of California, and Veterans Affairs Medical Center, San Diego, California 92161; and *National Cancer Institute, Bethesda, Maryland 20892

\begin{abstract}
Secretory proteins are targeted into either constitutive (secreted upon synthesis) or regulated (stored in vesicles and released in response to a secretagogue) pathways. To investigate mechanisms of protein targeting into catecholamine storage vesicles (CSV), we stably expressed human chromogranin A (CgA), the major soluble protein in human $\mathrm{CSV}$, in the rat pheochromocytoma PC-12 cell line. Chromaffin cell secretagogues (0.1 $\mathrm{mM}$ nicotinic cholinergic agonist, $55 \mathrm{mM} \mathrm{K} \mathrm{K}^{+}$, or 2 $\mathrm{mM} \mathrm{Ba}^{++}$) caused cosecretion of human $\mathrm{CgA}$ and catecholamines from human $\mathrm{CgA}$-expressing cells. Sucrose gradients colocalized human $\mathrm{CgA}$ and catecholamines to subcellular particles of the same buoyant density. Chimeric proteins, in which human $\mathrm{CgA}$ (either full-length [457 amino acids] or truncated [amino-terminal 226 amino acids]) was fused in-frame to the ordinarily nonsecreted protein chloramphenicol acetyltransferase (CAT), were expressed transiently in PC-12 cells. Both constructs directed CAT activity into regulated secretory vesicles, as judged by secretagogue-stimulated release. These data demonstrate that human $\mathrm{CgA}$ expressed in PC-12 cells is targeted to regulated secretory vesicles. In addition, human $\mathrm{CgA}$ can divert an ordinarily non-secreted protein into the regulated secretory pathway, consistent with the operation of a dominant targeting signal for the regulated pathway within the peptide sequence of CgA. (J. Clin. Invest. 1993. 92:1042-1054.) Key words: catecholamine $\bullet$ chromaffin cells $\bullet$ chromogranin A $\bullet$ PC12 - pheochromocytoma $\bullet$ regulated secretion
\end{abstract}

\section{Introduction}

Secretory proteins are targeted into either constitutive or regulated pathways $(1,2)$. Proteins entering the regulated pathway are concentrated and stored in vesicles, and subsequently released upon stimulation by a secretagogue. In the constitutive pathway, newly synthesized protein is not stored but leaves the Golgi complex in short-lived membrane vesicles that fuse immediately with the plasma membrane even in the absence of any extracellular signal.

Catecholamine storage vesicles are specialized subcellular organelles within chromaffin cells of the adrenal medulla and in sympathetic neurons (3). In addition to catecholamines,

Address reprint requests to Dr. Robert J. Parmer, Nephrology/Hypertension (V-111-H), University of California, San Diego, 3350 La Jolla Drive, San Diego, CA 92161.

Received for publication 5 June 1992 and in revised form 12 February 1993.

J. Clin. Invest.

(C) The American Society for Clinical Investigation, Inc.

$0021-9738 / 93 / 08 / 1042 / 13 \quad \$ 2.00$

Volume 92, August 1993, 1042-1054 these organelles contain ATP, $\mathrm{Ca}^{++}$, peptides, and proteins (4, 5 ), all of which are released in response to secretagogues by the process of exocytosis (6). These vesicles are thus an example of regulated secretory vesicles. The mechanisms of assembly of catecholamine storage vesicles, and, in particular, how proteins are targeted to such vesicles are poorly understood.

Chromogranin $\mathrm{A}(\mathrm{CgA})^{1}$ is the major soluble protein in the core of catecholamine storage vesicles (7) and is found as well in dense core secretory vesicles throughout the neuroendocrine system (8-11). In addition, recent evidence suggests that $\mathrm{CgA}$ and other members of the chromogranin/secretogranin ("granin") family of proteins may have a central role in the packaging of other proteins into the regulated secretory pathway (12). Thus, CgA may be a model protein for studies of protein targeting into the regulated pathway of secretion. Also, $\mathrm{CgA}$ is the source of biologically active peptides, such as pancreastatin (13), which suppresses islet beta cell secretion, and chromostatin, which suppresses secretagogue-stimulated catecholamine release (14).

To investigate mechanisms of protein targeting into catecholamine storage vesicles, we expressed human chromogranin A in the rat PC-12 cell line, a catecholaminergic rat pheochromocytoma cell line (15), which exhibits both regulated and constitutive pathways for secretion and sorts secreted proteins into one or the other of these pathways $(16,17)$. In the present report, we demonstrate the expression of human $\mathrm{CgA}$ in rat pheochromocytoma cells, the targeting of expressed human $\mathrm{CgA}$ to dense core catecholamine storage vesicles, and the ability of human $\mathrm{CgA}$ to divert a heterologous, ordinarily nonsecreted protein (chloramphenicol acetyltransferase [CAT]) into the regulated secretory pathway. In addition, we demonstrate that information sufficient for regulated vesicular targeting is contained within the amino-terminal half of the human $\mathrm{CgA}$ peptide sequence.

\section{Methods}

\section{Construction of the expression vector, $p R S V-h C g A$}

The mammalian expression vector, $\mathrm{pRSV}-\mathrm{hCgA}$, containing the fulllength human $\mathrm{CgA}$ cDNA under the control of the Rous sarcoma virus long-terminal repeat (RSV-LTR) was constructed as shown in Fig. 1. pGEM-hCgA (from Dr. Lee Helman, National Cancer Institute) was the source of the human CgA cDNA (18). pRSV-L (from Dr. Suresh Subramani, University of California, San Diego)(19) was the source of the RSV-LTR. After conversion of the SmaI site to an Xhol site in pRSV-L with synthetic linkers and subsequent digestion of resultant vector $\mathrm{pRSV}-\mathrm{L}_{1}$ with HindIII and $\mathrm{XhoI}$ to remove the firefly luciferase gene, the human $\mathrm{CgA}$ cDNA (liberated from pGem-hCgA by digestion with HindIII and SalI) was spliced into this HindIII-Xhol site. (Cohe-

1. Abbreviations used in this paper: CAT, chloramphenicol acetyltransferase; CgA, chromogranin A; RSV-LTR, Rous sarcoma virus-long terminal repeat. 


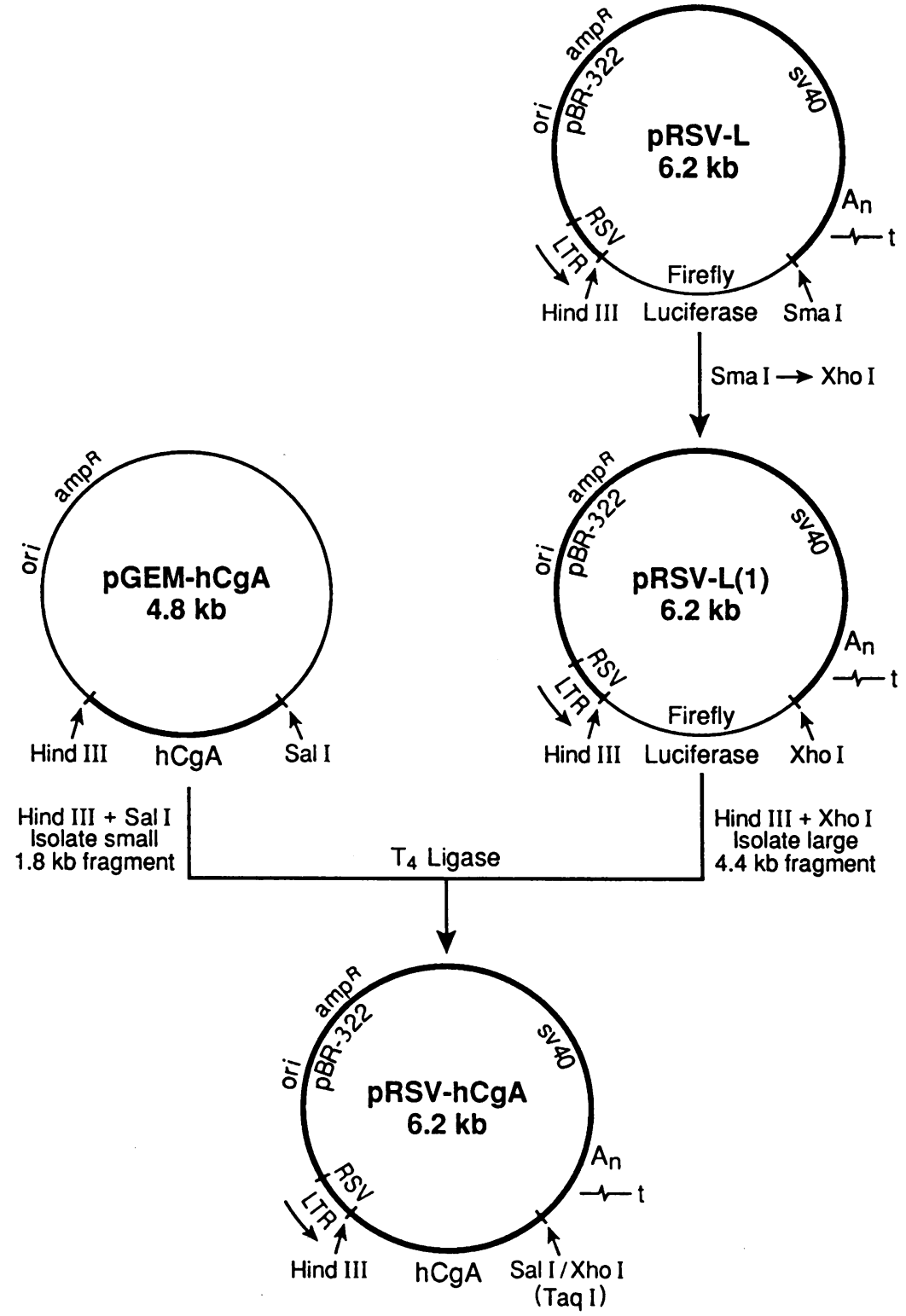

Figure 1. Construction of the expression vector, pRSV-hCgA, containing the full-length human $\mathrm{CgA}$ cDNA under the control of the RSV-LTR. pGEMhCgA was the source of the human CgA cDNA (18). pRSV-L was the source of the RSV-LTR (19). After conversion of the SmaI site to an XhoI site in pRSV-L with synthetic linkers and subsequent digestion of pRSV- $\mathrm{L}_{1}$ with HindIII and XhoI to remove the firefly luciferase gene, the human $\mathrm{CgA}$ cDNA (liberated from $\mathrm{pGem}-\mathrm{hCgA}$ by digestion with HindIII and SalI) was spliced into this HindIII-XhoI site. (Cohesive ends from Xhol and SalI digestions are compatible; subsequent ligation results in loss of Sal I and Xhol recognition sites and generation of a TaqI site.) The resultant construct contains the human $\mathrm{CgA}$ cDNA under the control of RSV-LTR, SV40 small t splice signal and polyadenylation signal $\left(A_{n}\right)$ for efficient message processing, and a prokaryotic segment from pBR-322 including the origin of replication (ori) and $\beta$-lactamase gene $\left(a m p^{\mathrm{R}}\right)$ for growth in $E$. coli. sive ends from XhoI and SalI digestions are compatible; subsequent ligation results in loss of Sal I and XhoI recognition sites and generation of a TaqI site.) The resultant construct contains the human $\mathrm{CgA}$ cDNA under the control of RSV-LTR, an SV40 small t splice signal and polyadenylation signal $\left(A_{n}\right)$ for efficient message processing, and a prokaryotic segment from pBR-322 including the origin of replication (ori) and $\beta$-lactamase gene $\left(\mathrm{amp}^{\mathrm{R}}\right)$ for growth in Escherichia coli. Construction was verified by diagnostic restriction digests and DNA sequencing.

\section{Cell culture}

Rat pheochromocytoma PC-12 cells (obtained from Dr. Bruce Howard of University of California, Los Angeles) were grown at $37^{\circ} \mathrm{C}, 6 \%$ $\mathrm{CO}_{2}$, in $10-\mathrm{cm}$ plates in DME medium supplemented with $5 \%$ FCS, $10 \%$ horse serum, $100 \mathrm{U} / \mathrm{ml}$ penicillin, and $100 \mu \mathrm{g} / \mathrm{ml}$ streptomycin.

\section{Stable transfection of rat pheochromocytoma PC-12 cells}

Using the calcium phosphate method (20), PC-12 cells (at 20-30\% confluence) were cotransfected with $10 \mu \mathrm{g} \mathrm{pRSV}-\mathrm{hCgA}$ plus $2 \mu \mathrm{g}$ of the plasmid pSV2-neo (21), which encodes bacterial phosphostransferase and confers neomycin resistance. Control cells were transfected with pSV2-neo alone. Transfected cells were selected with the antibiotic Geneticin (G418; Gibco BRL Life Technologies, Inc., Gaithersburg,
MD) at $0.5 \mathrm{mg} / \mathrm{ml}$ (active). Individual stable clones were recovered, transferred to separate wells of 24-well plates for subculture, and grown to mass culture in $10-\mathrm{cm}$ plates. Homogenates of stably transfected cells were obtained by resuspension of harvested cell pellets in $50 \mathrm{mM}$ ammonium acetate, $\mathrm{pH} 6.5,0.1 \%$ Triton $\mathrm{X}-100$, followed by two freeze-thaw cycles to promote cell disruption. Homogenates were screened for the production of human $\mathrm{CgA}$ by RIA specific for human $\mathrm{CgA}(22)$.

\section{SDS-PAGE and immunoblotting}

Prestained molecular weight size standards, $15 \mu \mathrm{g}$ of protein from human pheochromocytoma chromaffin vesicle lysate, and $50 \mu \mathrm{g}$ of protein from cell lysates of PC-12 cells transfected with either pSV2-neo alone or pSV2-neo and pRSV-hCgA, were electrophoresed through $10 \%$ SDS-PAGE slab gels, transferred to nitrocellulose, and stained for immunoreactive human $\mathrm{CgA}$ with rabbit anti-human $\mathrm{CgA}$ antisera (22) followed by visualization with peroxidase coupled goat anti-rabbit IgG plus the chromogenic substrate 4-chloro-1-naphthol.

\section{Electron microscopy of $P C-12$ cells}

Stably transfected or wild-type PC-12 cells were grown in Permanox (Lux, Tucson, AZ) culture dishes, washed three times in PBS ( $\mathrm{pH} 7.4$ ) 


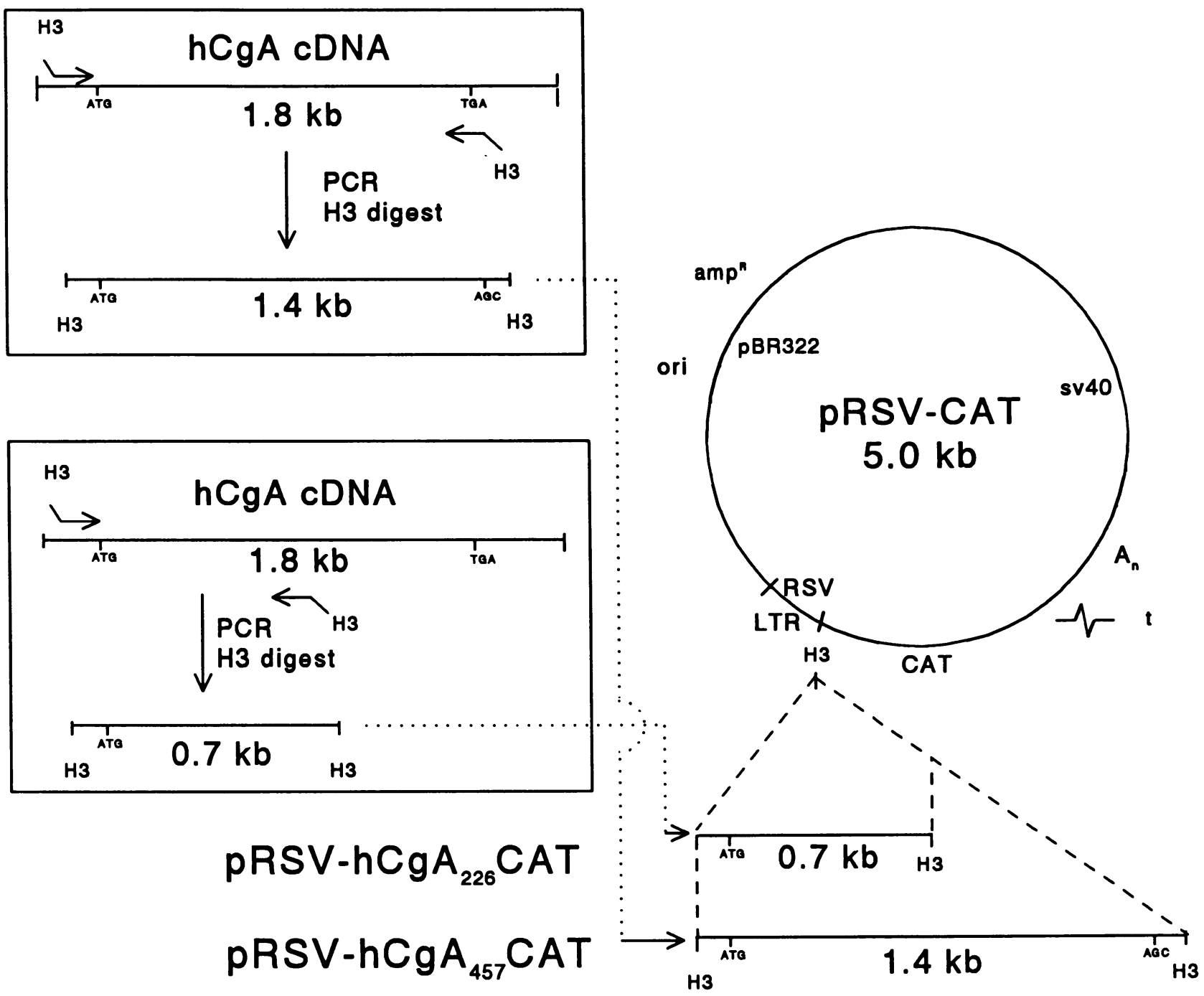

B

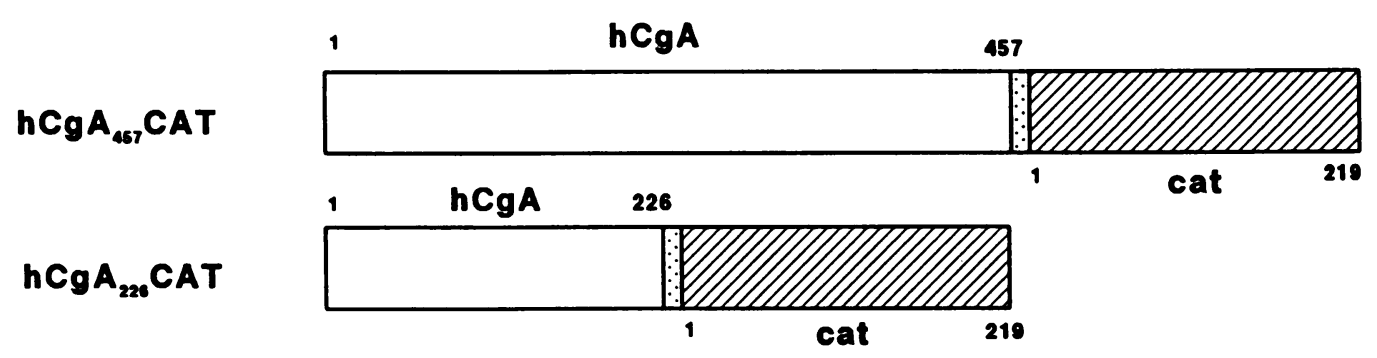

Figure 2. (A) Construction of the expression vectors pRSV-hCgA ${ }_{457}-\mathrm{CAT}$ and $\mathrm{pRSV}-\mathrm{hCgA}{ }_{226}-\mathrm{CAT}$. The expression vector $p R S V-h C g A_{457}-C A T$ encoding the full-length human $\mathrm{CgA}$ fused in-frame to $\mathrm{CAT}$ was constructed as follows. Beginning with the full-length $1.8 \mathrm{~kb}$ human $\mathrm{CgA} \mathrm{cDNA}$ as template ( upper box), a 1.4-kb insert was synthesized with PCR methods (28), using synthesized primers which engineered unique Hind III sites (5'-AAATAAGCTTCGGCCCCACACCGCCA-3' as 5' primer and 5'-AAATAAGCTTCCCCGCCGTAGTGCCTG-3' as 3' primer) into the $5^{\prime}$ and $3^{\prime}$ termini of the final $1.4-\mathrm{kb}$ product. The PCR product contained the full open reading frame of human $\mathrm{CgA}$ but was altered by the 3 ' primer such that the stop codon of the initial human $\mathrm{CgA}$ cDNA was substituted with the codon AGC, encoding a serine residue and allowing translation to continue through this point; after Hind III digestion and purification, the PCR product was ligated into the unique Hind III site 
to remove growth media, and fixed at room temperature in modified Karnovsky's solution for $30 \mathrm{~min}$. After three buffer washes with $0.2 \mathrm{M}$ sodium cacodylate ( $\mathrm{pH} 7.4$ ), the cells were postfixed in buffered $1 \%$ osmium tetroxide for $30 \mathrm{~min}$. After three distilled water rinses, the cells were dehydrated in a graded ethanol series ( $3 \mathrm{~min}$ each) followed by a 10 -min wash series in $(90 \%, 95 \%, 97 \%)$ hydroxypropyl methacrylate. After dehydration, the cells were embedded in a thin layer (approximately one-fourth the depth of the dish ) of Epon 812. After polymerization in a $65^{\circ} \mathrm{C}$ oven, the hardened plastic containing the cells was removed from the dish and floated for $15 \mathrm{~s}$ in a near boiling solution of $1 \%$ toluidine blue in $1 \%$ sodium borate. Cells were cut out from the embedded plate of plastic and glued to blank blocks of Epon 812. Thin sections were cut and mounted on unsupported 200-mesh grids. Sections were stained in saturated ethanol-uranyl acetate and bismuth subnitrate before viewing in a model EM-10B electron microscope (Carl Zeiss, Inc., Thornwood, NY).

\section{Sucrose density gradient studies}

After G-418 selection, PC-12 cells stably transfected with pRSV-hCgA plus pSV2-neo or with pSV2-neo alone were labeled for $2 \mathrm{~h}$ with $\left[{ }^{3} \mathrm{H}\right]-$ norepinephrine (Amersham Corp., Arlington Heights, IL) at $1 \mu \mathrm{Ci} / \mathrm{ml}$ in PC-12 medium, washed twice with buffer $(150 \mathrm{mM} \mathrm{NaCl}, 5 \mathrm{mM}$ $\mathrm{KCl}, 2 \mathrm{mM} \mathrm{CaCl}_{2}, 1 \mathrm{mM}$ ascorbic acid, $10 \mathrm{mM}$ Hepes, $\mathrm{pH} 7$ ), homogenized in $0.3 \mathrm{M}$ sucrose, $10 \mathrm{mM}$ Hepes, $\mathrm{pH} 7$, layered over a continuous sucrose density gradient $(0.3-2.5 \mathrm{M})$, and centrifuged at $100,000 \mathrm{~g}$ for $60 \mathrm{~min}$ at $2^{\circ} \mathrm{C}$ as described (23-26). Fractions were collected and assayed for $\left[{ }^{3} \mathrm{H}\right]$ norepinephrine by liquid scintillation counting, human CgA by RIA, and sucrose concentration by refractometry.

\section{Secretagogue-mediated release of human $\mathrm{CgA}$ and norepinephrine}

PC-12 cells stably transfected with pRSV-hCgA plus pSV2-neo or with pSV2-neo alone were plated on poly-D-lysine-coated polystyrene dishes (Falcon, Labware, Oxnard, CA), labeled for $2 \mathrm{~h}$ with $\left[{ }^{3} \mathrm{H}\right]-$ norepinephrine at $1 \mu \mathrm{Ci} / \mathrm{ml}$ in PC-12 medium, washed twice with release buffer ( $150 \mathrm{mM} \mathrm{NaCl}, 5 \mathrm{mM} \mathrm{KCl}, 2 \mathrm{mM} \mathrm{CaCl}_{2}, 10 \mathrm{mM}$ Hepes, $\mathrm{pH} 7$ ), and incubated at room temperature (air-conditioned lab with near constant temperature readings $\left.\left[22.5 \pm 0.11^{\circ} \mathrm{C}, n=7\right]\right)$ for $30 \mathrm{~min}$ in release buffer with or without the following secretagogues: the nicotinic agonist carbamylcholine chloride (carbachol; Sigma Chemical Co., St. Louis, MO) at $0.1 \mathrm{mM}$; potassium chloride at $55 \mathrm{mM}$; or barium chloride at $2 \mathrm{mM}$. (Release buffer for experiments involving $\mathrm{KCl}$ as secretagogue included $\mathrm{NaCl}$ at $100 \mathrm{mM}$ and release buffer was devoid of $\mathrm{CaCl}_{2}$ when $\mathrm{BaCl}_{2}$ was used as secretagogue.) After aspirating the release buffer, cells were harvested and lysed in $150 \mathrm{mM} \mathrm{NaCl}, 5$ $\mathrm{mM} \mathrm{KCl}, 10 \mathrm{mM}$ Hepes, $\mathrm{pH} 7$, and $0.1 \%$ Triton X-100. Release buffer and cell lysates were assayed for human $\mathrm{CgA}$ by RIA and $\left[{ }^{3} \mathrm{H}\right]-$ norepinephrine by liquid scintillation counting, and results were expressed as percent secreted: amount in release buffer/total (amount in release buffer + amount in cell lysate). In addition, release of norepinephrine and human $\mathrm{CgA}$ from transfected PC-12 cells was determined after exposure for $30 \mathrm{~min}$ to the weak bases chloroquine at 1 $\mathrm{mM}$ or ammonium chloride at $10 \mathrm{mM}$.

\section{Human CgA radioimmunoassay}

Human $\mathrm{CgA}$ was assayed as previously described by species specific RIA, which recognizes human but not rat (including endogenous PC12) epitopes (22).

Protein concentrations on lysates of transfected cells and on lysates of chromaffin vesicles prepared from human pheochromocytoma tumors (5) were determined by the Coomassie Blue dye binding technique (27).

\section{Human $\mathrm{CgA} / \mathrm{CAT}$ fusion studies}

Construction of the expression vectors $p R S V-h C g A_{45 T} C A T$ and $p R S V$ $h C g A_{22 \sigma} C A T$. An expression vector ( $\mathrm{pRSV}-\mathrm{hCgA} \mathrm{A}_{45} \mathrm{CAT}$ ) encoding a chimeric protein consisting of full-length human $\mathrm{CgA}$ fused in-frame to the bacterial enzyme CAT was constructed as diagrammed in Fig. 2. Beginning with the full-length human $\mathrm{CgA}$ cDNA as template, a 1.4-kb insert was synthesized with standard PCR methods (28), using Vent DNA polymerase (New England Biolabs, Beverly, MA), a thermostable high-fidelity DNA polymerase with 3 '-5' proofreading exonuclease activity (29), $50 \mathrm{mM}$ dNTPs in PCR buffer [10 $\mathrm{mM} \mathrm{KCl}, 10 \mathrm{mM}$ $\left(\mathrm{NH}_{4}\right)_{2} \mathrm{SO}_{4}, 20 \mathrm{mM}$ Tris- $\mathrm{HCl}, \mathrm{pH} 8.0,5 \mathrm{mM} \mathrm{MgSO}_{4}, 0.1 \%$ Triton $\mathrm{X}-100$ ], and synthetic primers (at 20 pmol each) which engineered unique Hind III sites (5'-AAATAAGCTTCGGCCCCACACCGCCA$3^{\prime}$ as 5' primer and 5'-AAATAAGCTTCCCCGCCGTAGTGCCTG-3' as $3^{\prime}$ primer) into the $5^{\prime}$ and $3^{\prime}$ termini of the final $1.4-\mathrm{kb}$ product, using 35 cycles of $94^{\circ} \mathrm{C}$ for $1 \mathrm{~min}, 42^{\circ} \mathrm{C}$ for $1 \mathrm{~min}$, and $65^{\circ} \mathrm{C}$ for $1.5 \mathrm{~min}$, in an EZ Cycler thermocycler (Ericomp., Inc., San Diego, CA). The product contained the full open reading frame of human $\mathrm{CgA}$ but was altered by the $3^{\prime}$ primer such that the stop codon of the initial human $\mathrm{CgA}$ cDNA was substituted with the codon AGC, encoding a serine residue and allowing translation to continue through this point; the PCR product was digested at $37^{\circ} \mathrm{C}$ for $18 \mathrm{~h}$ with Hind III, purified on a $1 \%$ agarose gel, and ligated into the unique Hind III site of the expression vector pRSV-CAT (30). The resultant construct contains the RSV-LTR promoter driving full-length human $\mathrm{CgA}$ cDNA (encoding 457 amino acid residues) fused in-frame to the full-length CAT-encoding region. Also, since the Hind III cloning site in pRSV-CAT is $36 \mathrm{bp}$ upstream of the ATG initiation codon for CAT, expression of the final fusion product results in the insertion of an additional 12 amino acid residues (SLARFSGAKEAKM) between full-length human $\mathrm{CgA}$ and CAT.

An additional expression vector ( $\mathrm{pRSV}-\mathrm{hCgA} \mathrm{A}_{226}-\mathrm{CAT}$ ) containing a mutated human $\mathrm{CgA}$ cDNA encoding the amino-terminal 226 amino acid residues of human $\mathrm{CgA}$ (including the 18-residue signal peptide plus the amino-terminal 208 residues of mature $\mathrm{CgA}$ after signal peptide cleavage) fused in-frame to $C A T$ was also constructed using the above PCR methods with 5'-AAATAAGCTTCGGCCCCACACCGCCA-3' as 5' primer and 5'-AAATAAGCTTGCCTGCCACCCTGG-3' as the $3^{\prime}$ primer and full-length human $\mathrm{CgA}$ cDNA as template. The resultant $0.7-\mathrm{kb}$ product was digested with Hind III and inserted into the Hind III cloning site of pRSV-CAT as above. The final construct contains the coding region for the amino-terminal 226 amino acid residues of human $\mathrm{CgA}$ fused in-frame to the coding region for

of the expression vector pRSV-CAT (30). The vector $p R S V-h C g A_{226}-C A T$ containing a mutated human $C g A$ cDNA encoding the amino-terminal 226 amino acid residues of human $\mathrm{CgA}$ (including the 18-residue signal peptide plus the amino-terminal 208 residues of mature $\mathrm{CgA}$ after signal peptide cleavage) fused in frame to CAT was constructed using PCR methods with the primers, 5'-AAATAAGCTTCGGCCCCACACCGCCA-3' as 5' primer and 5'-AAATAAGCTTGCCTGCCACCCTGG-3' as the 3' primer and the full-length human CgA cDNA as template (lower box). The resultant $0.7-\mathrm{kb}$ product was digested with Hind III and inserted into the Hind III cloning site of pRSV-CAT as above. (Hinged arrows represent synthesized primers for PCR; H3 indicates Hind III sites.) (B) Structure of CgA/CAT fusion proteins. Predicted expression products of pRSV-hCgA $457-\mathrm{CAT}\left(h C g A_{457} C A T\right)$ and $\mathrm{pRSV}-\mathrm{hCgA}{ }_{226}-\mathrm{CAT}\left(h C g A_{226} C A T\right)$. The human $\mathrm{CgA}$ and $\mathrm{CAT}$ sequences are designated by the open and hatched bars, respectively. Numerals above each bar refer to the amino acid positions of the human $\mathrm{CgA}$ sequence (before signal peptide cleavage). Numerals below each bar refer to the amino acid positions of CAT. The stippled area represents a 12-amino acid insertion (SLARFSGAKEAKM) caused by expression of the 36-bp DNA sequence between the HindIII cloning site and the ATG initiation codon for CAT in the parent pRSV-CAT vector. The first 18 amino acid residues of hCgA constitute the hydrophobic signal peptide sequence responsible for targeting the nascent polypeptide to the membrane of the rough endoplasmic reticulum and thus allowing for entry into the secretory pathway. 
CAT, under the control of the RSV-LTR. Expression of the final fusion product of this vector results in the insertion (between the 226 aminoterminal amino acid residues of human $\mathrm{CgA}$ and CAT) of the same additional 12 amino acid residues (SLARFSGAKEAKM) described above for $\mathrm{pRSV}-\mathrm{hCgA} \mathrm{As}_{45} \mathrm{CAT}$. Both of these expression vectors ( $\mathrm{pRSV}-\mathrm{hCgA} \mathrm{A}_{45}$-CAT and $\mathrm{pRSV}-\mathrm{hCgA} \mathrm{A26}_{26}$-CAT) were analyzed by restriction endonuclease mapping to confirm orientations, and fragment junctions were confirmed by DNA sequencing in both cases.

Transient transfection of PC-12 cells. PC-12 cells grown to 50\% confluence in $6-\mathrm{cm}$ plates were transfected using the lipofection procedure $\left(31,32\right.$ ) with $20 \mu \mathrm{g}$ of plasmid DNA (either pRSV-hCgA ${ }_{457}-\mathrm{CAT}$, pRSV-hCgA ${ }_{226}-\mathrm{CAT}$, pRSV-CAT, or pBluescript [Stratagene, Inc., La Jolla, CA] as a mock transfection control) and $20 \mu \mathrm{g}$ of lipofectant (Gibco BRL Life Technologies, Inc.). After 48-60 h, transfected cells were analyzed by metabolic labeling and immunoprecipitation to confirm translation products, or by secretagogue-stimulation to investigate corelease of $\left[{ }^{3} \mathrm{H}\right]$ norepinephrine and CAT activity as described below.

Metabolic labeling and immunoprecipitation. Transiently transfected PC-12 cells were starved for $1 \mathrm{~h}$ in methione-free medium, then labeled with $50 \mu \mathrm{Ci} /$ plate $\left[{ }^{35} \mathrm{~S}\right]$ methionine (ICN Biochemicals, Inc., Costa Mesa, CA) for $4 \mathrm{~h}$ at $37^{\circ} \mathrm{C}$. Cells were washed with PBS and lysed in $0.1 \mathrm{M} \mathrm{NaCl}, 0.1 \mathrm{M}$ Tris, pH 8.0, $10 \mathrm{mM}$ EDTA, $1 \%$ Triton X-100, 1 $\mathrm{mM}$ PMSF (Sigma Chemical Co.), and $50 \mathrm{KIU} / \mathrm{ml}$ aprotinin (Calbiochem Corp., La Jolla, CA). Cell debris was removed by centrifugation and $75 \mu \mathrm{l}$ of each of the cell supernatants were incubated with $2 \mu \mathrm{l}$ of preimmune serum for $1 \mathrm{~h}$ at $4^{\circ} \mathrm{C}$, followed by $10 \mu \mathrm{l} 50 \%$ protein $\mathrm{A}$ Sepharose (Pharmacia-LKB Biotechnology, Inc., Piscataway, NJ) for 30 min at $4^{\circ} \mathrm{C}$ on a shaker platform, to reduce nonspecific binding. After centrifugation, the supernatants were incubated for $18 \mathrm{~h}$ at $4^{\circ} \mathrm{C}$ with either $2 \mu$ l of polyclonal anti-CAT antibody (Five Prime to Three Prime, Inc., Boulder, $\mathrm{CO}$ ) or $10 \mu \mathrm{L}$ polyclonal rabbit anti-human $\mathrm{CgA}$ antiserum (22). After incubation with $20 \mu \mathrm{l}$ of $50 \%$ protein A Sepharose for $2 \mathrm{~h}$ at $4^{\circ} \mathrm{C}$ and centrifugation, the pellets were washed, boiled for $5 \mathrm{~min}$, and electrophoresed through 8\% SDS-polyacrylamide gels. The gels were placed in the enhancing solution Resolution (EM Corp., Chestnut Hill, MA) for 45 min, then placed in 5\% cold glycerol for 45 minutes, dried, and exposed at $-80^{\circ} \mathrm{C}$ to Kodak X-OMAT AR film (Eastman Kodak Co., Rochester, NY).

Secretagogue stimulation of transiently transfected cells. 48-60 h after transfection with the above constructs, PC-12 cells, grown in polyD-lysine-coated polystyrene dishes (Falcon Labware), were labeled for $2 \mathrm{~h}$ with $\left[{ }^{3} \mathrm{H}\right]$ norepinephrine at $1 \mu \mathrm{Ci} / \mathrm{ml}$ in $\mathrm{PC}-12$ medium, washed twice with release buffer $(150 \mathrm{mM} \mathrm{NaCl}, 5 \mathrm{mM} \mathrm{KCl}, 10 \mathrm{mM}$ Hepes,

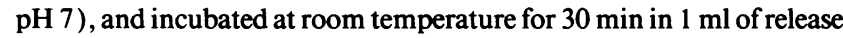
buffer with or without the secretagogue barium chloride at $2 \mathrm{mM}$. After aspirating the release buffer, cells were harvested in $1 \mathrm{ml}$ of $150 \mathrm{mM}$ $\mathrm{NaCl}, 5 \mathrm{mM} \mathrm{KCl}, 10 \mathrm{mM}$ Hepes, $\mathrm{pH} \mathrm{7,} \mathrm{and} \mathrm{lysed} \mathrm{with} \mathrm{three} \mathrm{freeze-}$ thaw cycles. Release buffer and cell lysates were assayed for $\left[{ }^{3} \mathrm{H}\right]-$ norepinephrine by liquid scintillation counting and for CAT activity by the method of organic extraction with ethyl acetate (33). Briefly, the CAT activity assay mixture contained (in a final volume of $250 \mu \mathrm{l}$ ) 177 $\mu \mathrm{l}$ of $50 \mathrm{mM}$ Tris- $\mathrm{HCl}, \mathrm{pH} \mathrm{7.5,70 \mu l}$ of release buffer or cell lysate (heat inactivated at $65^{\circ} \mathrm{C}$ for $\left.10 \mathrm{~min}\right), 1 \mu \mathrm{l}(0.05 \mu \mathrm{Ci})$ of $\left[{ }^{14} \mathrm{C}\right]$ acetyl coenzyme A ( $55 \mathrm{mCi} / \mathrm{mmol}$; Amersham Corp.), $1 \mu \mathrm{l}$ of $37 \mathrm{mg} / \mathrm{ml}$ chloramphenicol (United States Biochemical Corp., Cleveland, $\mathrm{OH}$ ), and 1 $\mu \mathrm{l}$ of $25 \mathrm{mM}$ acetyl coenzyme A (Sigma Chemical Co.). After incubation for $120 \mathrm{~min}$ at $37^{\circ} \mathrm{C}$, the assay mixture was extracted twice with $250 \mu$ of ethyl acetate and the organic phase was assayed for $\left[{ }^{14} \mathrm{C}\right]-$ chloramphenicol by liquid scintillation counting. Results are expressed as percent secreted (of either $\left[{ }^{3} \mathrm{H}\right]$ norepinephrine or CAT activity): amount in release buffer/total (amount in release buffer + amount in cell lysate).

In additional control experiments, release of $\left[{ }^{3} \mathrm{H}\right]$ norepinephrine and CAT activity was assessed in cells transiently transfected with an expression vector, $\mathrm{pRSV}$-v-sis ${ }_{\mathrm{sp}} \mathrm{CAT}$, in which the signal peptide from the secretory protein, v-sis (a signal sequence which has been extensively characterized in transfected mammalian cells [34-36]), was

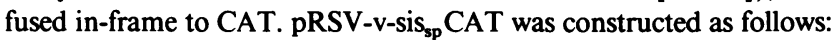

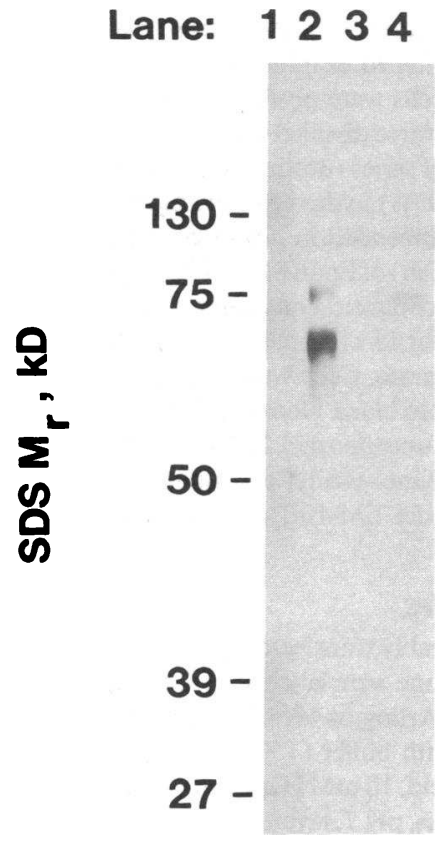

Figure 3. Expression of human $\mathrm{CgA}$ in PC- 12 cells. Prestained molecular weight size standards (lane 1 ), 15 $\mu \mathrm{g}$ of protein from human pheochromocytoma chromaffin vesicle lysate (lane 2 ), and $50 \mu \mathrm{g}$ of protein from cell lysates of PC- 12 cells transfected with either pSV2neo alone (lane 3 ) or pSV2neo and pRSV-hCgA (lane 4), were electrophoresed through 10\% SDS-PAGE slab gels, transferred to nitrocellulose, and stained for immunoreactive human $\mathrm{CgA}$ with rabbit anti-human $\mathrm{CgA}$ antisera followed by visualization with peroxidase coupled goat anti-rabbit IgG plus the chromogenic substrate 4chloro-1-naphthol. Human $\mathrm{CgA}($ at $75 \mathrm{kD}$ ) is detected in human pheochromocytoma cell lysate (lane 2) and PC-12 cells transfected with pSV2-neo and pRSV-hCgA (lane 4), but not in PC-12 cells transfected with pSV2-neo alone (lane 3).

using the above PCR conditions, a 0.2-kb cDNA fragment ( within Sal I and Xho I sites in the vector pDD184, from Dr. Dan Donoghue, University of California, San Diego [34]) encoding the v-sis signal peptide (34), was inserted between the RSV-LTR promoter and the coding region for CAT. The final construct contains the coding region for the amino-terminal 59 amino acid residues of v-sis, fused in-frame to the full-length coding region for CAT, under the control of the RSV-LTR. As for all other plasmid constructions, the vector was analyzed by restriction endonuclease mapping to confirm orientations, and fragment junctions were confirmed by DNA sequencing.

\section{Statistics}

Results of secretion experiments are expressed as mean \pm SEM. Results were analyzed by ANOVA followed by Student-Newman-Keuls posthoc tests for multiple comparisons (37).

\section{Results}

\section{Expression of human $\mathrm{CgA}$ in $\mathrm{PC}-12$ cells}

Human $\mathrm{CgA}$ immunoreactivity was detected in cell homogenates from five of six recovered clones of PC- 12 cells co-transfected with pRSV-hCgA and pSV2-neo and in none of six recovered clones of $\mathrm{PC}-12$ cells transfected with pSV2-neo alone as a control.

Fig. 3 shows Western blot analysis demonstrating expression of human $\mathrm{CgA}$ in stably transfected rat pheochromocytoma PC-12 cells (clone 2C). Human CgA is observed as an $\mathrm{M}_{\mathrm{r}}$ 75-kD band crossreacting with a species-specific anti-human $\mathrm{CgA}$ antibody in cells cotransfected with pRSV-hCgA and pSV2-neo, but not in control cells transfected with pSV2-neo alone (clone 4A).

\section{Electron microscopy}

Transmission electron micrographs of PC-12 cells cotransfected with pRSV-hCgA and pSV2-neo are shown in Fig. 4, demonstrating normal-appearing dense core secretory vesicles in a typical distribution at the cell periphery. Cell appearance, 

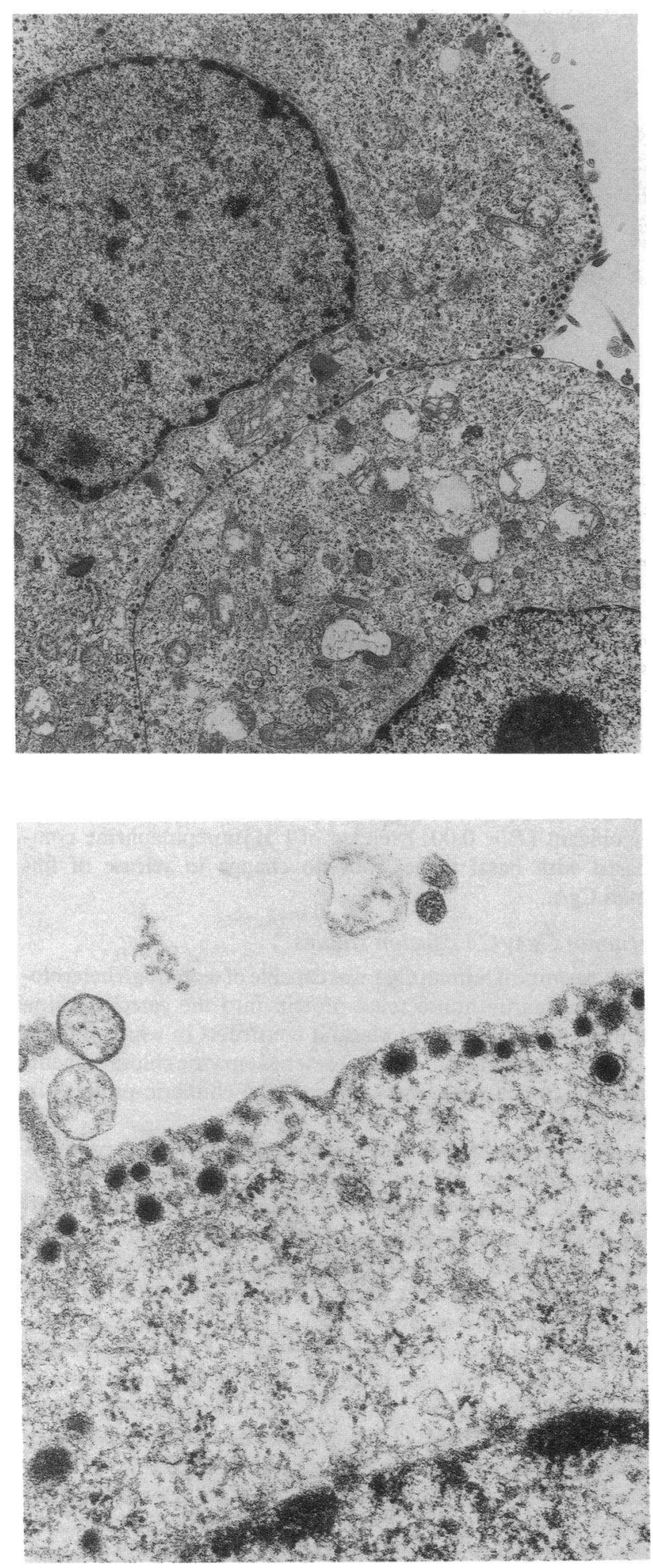

Figure 4. Transmission electron micrographs of PC-12 cells cotransfected with pRSV-hCgA and pSV2-neo, demonstrating normally appearing dense core secretory vesicles (catecholamine storage vesicles) in a typical distribution at the cell periphery. Cell appearance, number, and distribution of dense core secretory vesicles did not differ from cells transfected with pSV2-neo alone or from wild-type PC-12 cells. Magnification is 15,840 diameters for upper panel and 79,200 diameters for lower panel. number, and distribution of dense core secretory vesicles did not differ from cells transfected with pSV2-neo alone or from wild-type PC-12 cells (data not shown).

\section{Subcellular localization studies}

Sucrose gradient studies. To investigate the subcellular localization of the expressed human $\mathrm{CgA}$ in PC-12 cells transfected with pRSV-hCgA and pSV2-neo, cells were subjected to sucrose density gradient fractionation, the results of which are shown in Fig. 5. In cells transfected with pRSV-hCgA and

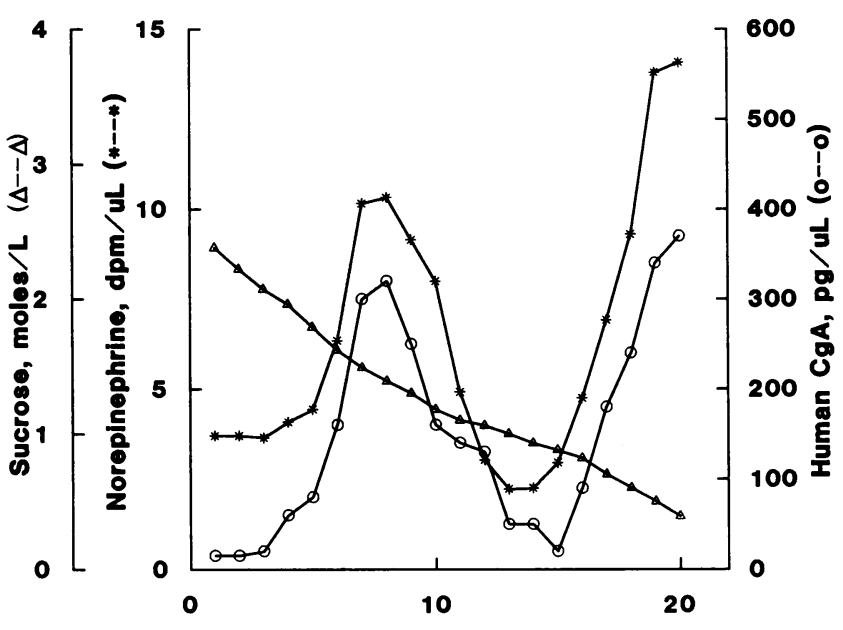

FRACTION

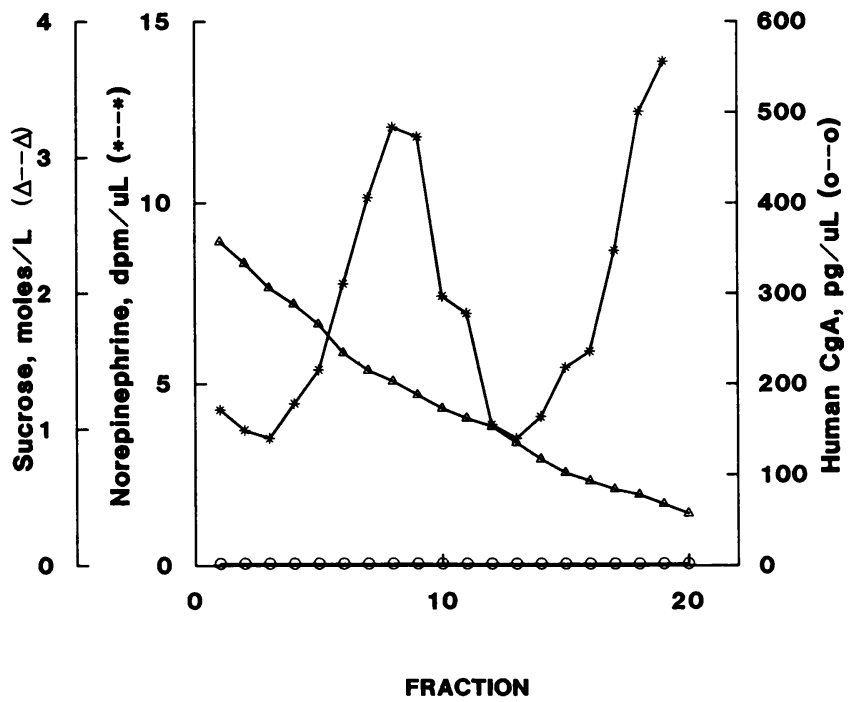

Figure 5. Sucrose gradient studies. PC-12 cells transfected with pRSV-hCgA and pSV2-neo (Clone 2C, upper panel) were labeled with $\left[{ }^{3} \mathrm{H}\right]$ norepinephrine, homogenized in $0.3 \mathrm{M}$ sucrose, $10 \mathrm{mM}$ Hepes, $\mathrm{pH} 7$, layered over a continuous sucrose gradient (0.3-2.5 $\mathrm{M})$, and centrifuged at $100,000 \mathrm{~g}$ for $60 \mathrm{~min}$ at $2^{\circ} \mathrm{C}$. Fractions were collected, lysed by addition of Triton X-100 to a final concentration of $0.1 \%$, and assayed for $\left[{ }^{3} \mathrm{H}\right]$ norepinephrine by liquid scintillation counting, human $\mathrm{CgA}$ by RIA, and sucrose concentration by refractometry. Results showed colocalization of transfected $\mathrm{CgA}$ and norepinephrine to the same subcellular fraction at a buoyant density of 1.3-1.4 M sucrose. Control PC-12 cells transfected with pSV2-neo alone (Clone 4A, lower panel) also showed a norepinephrine peak at 1.3-1.4 $\mathrm{M}$ sucrose but no detectable $\mathrm{CgA}$. 
pSV2-neo, there was colocalization of transfected human $\mathrm{CgA}$ and norepinephrine to the same subcellular fraction at a buoyant density of 1.3-1.4 M sucrose. Control PC-12 cells transfected with pSV2-neo alone also showed a norepinephrine peak at 1.3-1.4 M sucrose but no detectable human $\mathrm{CgA}$.

Secretagogue-mediated corelease of human CgA and catecholamine. Subcellular localization of the expressed human $\mathrm{CgA}$ was also investigated by experiments in which release of both human $\mathrm{CgA}$ and $\left[{ }^{3} \mathrm{H}\right]$ norepinephrine was determined after transfected cells were exposed to a variety of secretagogues (Fig. 6). Exposure of PC-12 cells stably transfected with pRSVhCgA plus pSV2-neo to the nicotinic agonist carbamylcholine at $0.1 \mathrm{mM}$, to $55 \mathrm{mM} \mathrm{KCl}$, or to $2 \mathrm{mM} \mathrm{BaCl}_{2}$, resulted in significant release over baseline (no secretagogue) of both $\left[{ }^{3} \mathrm{H}\right]-$ norepinephrine $(P<0.001$ for all three agents) and human $\mathrm{CgA}(P<0.001$ for all three agents $)$. Secretion of human $\mathrm{CgA}$ paralleled norepinephrine secretion. Control experiments on PC-12 cells transfected with pSV2-neo alone showed secretion of $\left[{ }^{3} \mathrm{H}\right]$ norepinephrine in response to secretagogue but no detectable human $\mathrm{CgA}$ in either basal or stimulated states.

Effect of alkalinizing agents. PC-12 cells stably expressing human $\mathrm{CgA}$ were also exposed to the weak bases (lysosomotropic amines) chloroquine $(1 \mathrm{mM})$ or ammonium chloride ( 10 $\mathrm{mM}$ ), which act as alkalinizing agents to disrupt intravesicular acidification (38). Fig. 7 demonstrates that exposure of the

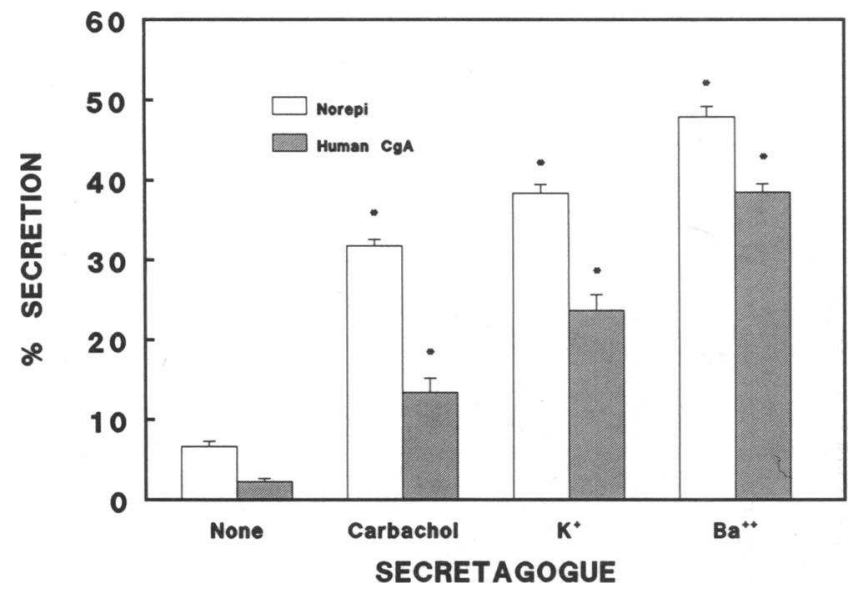

Figure 6. Secretion of human $\mathrm{CgA}$ and norepinephrine from transfected PC-12 cells: effect of carbachol, potassium, and barium. PC-12 cells transfected with pRSV-hCgA and pSV2-neo (clone 2C) were labeled with $\left[{ }^{3} \mathrm{H}\right]$ norepinephrine and incubated at room temperature for $30 \mathrm{~min}$ in release buffer ( $150 \mathrm{mM} \mathrm{NaCl}, 5 \mathrm{mM} \mathrm{KCl}, 2 \mathrm{mM} \mathrm{CaCl}_{2}$, $10 \mathrm{mM}$ Hepes, $\mathrm{pH} 7$ ) with or without the following secretagogues: the nicotinic agonist carbamylcholine, $0.1 \mathrm{mM}$ (carbachol); $\mathrm{KCl}, 55$ $\mathrm{mM}\left(\mathrm{K}^{+}\right)$, and $\mathrm{BaCl}_{2}, 2 \mathrm{mM}\left(\mathrm{Ba}^{++}\right)$. (Release buffer for experiments involving $\mathrm{KCl}$ as secretagogue included $\mathrm{NaCl}$ at $100 \mathrm{mM}$ and release buffer was devoid of $\mathrm{CaCl}_{2}$ when $\mathrm{BaCl}_{2}$ was used as secretagogue). After aspirating the release buffer, cells were harvested and lysed in $150 \mathrm{mM} \mathrm{NaCl}, 5 \mathrm{mM} \mathrm{KCl}, 10 \mathrm{mM}$ Hepes, $\mathrm{pH} \mathrm{7,} \mathrm{and} 0.1 \%$ Triton $\mathrm{X}-100$. Release buffer and cell lysate were assayed for human $\mathrm{CgA}$ by RIA and $\left[{ }^{3} \mathrm{H}\right]$ norepinephrine and results expressed as percent secreted: amount in release buffer/total (release buffer + cell lysate). Each of the three secretagogues resulted in significant release of both $\left[{ }^{3} \mathrm{H}\right]$ norepinephrine (Norepi) and human $\mathrm{CgA}\left({ }^{*} P<0.001 \mathrm{com}\right.$ pared with corresponding basal values). Control experiments using PC-12 cells transfected with pSV2-neo showed secretion of norepinephrine in response to secretagogue but no detectable human $\mathrm{CgA}$ in either basal or stimulated states.

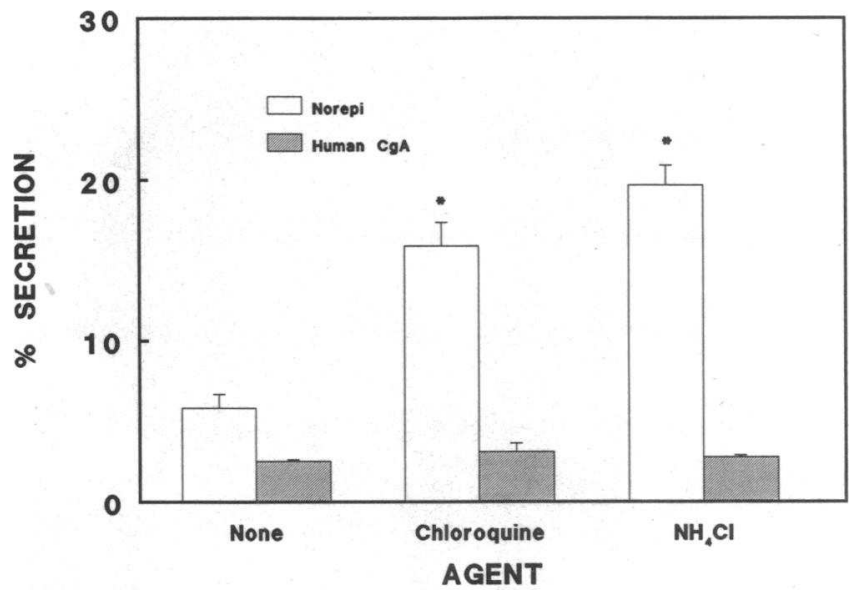

Figure 7. Secretion of human $\mathrm{CgA}$ and norepinephrine from transfected PC-12 cells: effect of alkalinizing agents. PC-12 cells transfected with pRSV-hCgA and pSV2-neo (clone $2 \mathrm{C}$ ) were labeled with $\left[{ }^{3} \mathrm{H}\right]-$ norepinephrine and incubated at room temperature in release buffer ( $150 \mathrm{mM} \mathrm{NaCl}, 5 \mathrm{mM} \mathrm{KCl}, 2 \mathrm{mM} \mathrm{CaCl}_{2}, 10 \mathrm{mM}$ Hepes, $\mathrm{pH} 7$ ) or with release buffer supplemented with alkalinizing agents (either 1 $\mathrm{mM}$ chloroquine or $10 \mathrm{mM} \mathrm{NH}_{4} \mathrm{Cl}$ ). Exposure to either agent resulted in a significant $\left({ }^{*} P<0.001\right)$ release of $\left[{ }^{3} \mathrm{H}\right]$ norepinephrine (Norepi) compared with values for basal (none), but no change in the release of human $\mathrm{CgA}$.

transfected cells to either of these agents was associated with significant $(P<0.001)$ release of $\left[{ }^{3} \mathrm{H}\right]$ norepinephrine compared with basal values, but no change in release of human CgA.

\section{Human CgA/CAT fusion studies}

To determine if human $\mathrm{CgA}$ was capable of directing a heterologous, ordinarily nonsecreted protein into the catecholamine storage vesicle, we made plasmid constructs in which human CgA was fused in-frame to the bacterial enzyme chloramphenicol acetyltransferase, and expressed the chimeric proteins in PC- 12 cells.

Fig. 8 shows SDS-PAGE analysis of the expression products of the plasmid vectors pRSV-hCgA $\mathrm{A}_{45}-\mathrm{CAT}$ and pRSV$\mathrm{hCgA}{ }_{226}-\mathrm{CAT}$ after transient transfection and metabolic labeling in PC-12 cells. Major product bands were immunoprecipitated in a nearly identical pattern with both anti-human $\mathrm{CgA}$ (Fig. 8, left panel) and anti-CAT antibodies (Fig. 8, right panel). Expression of pRSV-hCgA $\mathrm{A}_{457}-\mathrm{CAT}$ resulted in a major product band with a mobility on SDS-PAGE of $\sim 100-110$ $\mathrm{kD}$, consistent with that predicted for the full-length human CgA/CAT chimera ( $75 \mathrm{kD}$ for human $\mathrm{CgA}$ [see Fig. 3] plus 26.6 kD for CAT [39]. (Human CgA has a highly anomalous electrophoretic mobility in SDS polyacrylamide gels. Whereas the predicted molecular mass of $\mathrm{CgA}$ is $\sim 50 \mathrm{kD}$, the apparent molecular mass by SDS-PAGE is 70-75 $\mathrm{kD}[18,40-44$; and Fig. 3]). Expression of pRSV-hCgA ${ }_{226}-\mathrm{CAT}$ resulted in a major band of $\sim 60-65 \mathrm{kD}$, consistent with the approximate mobility predicted for fusion of 226 amino acid residues of human $\mathrm{CgA}$ to CAT $(226 / 457$ or $49 \%$ of $75 \mathrm{kD}=37 \mathrm{kD}$ for the $\mathrm{CgA}$ fragment; $37 \mathrm{kD}$ for this $\mathrm{CgA}$ fragment plus $26.6 \mathrm{kD}$ for CAT $=64 \mathrm{kD}$ for the $\mathrm{hCgA}_{226}$-CAT fusion product).

Cells transfected with the $\mathrm{CgA} / \mathrm{CAT}$ fusion constructs displayed CAT enzyme activity. We investigated the subcellular distribution of the transient expression products by evaluating 

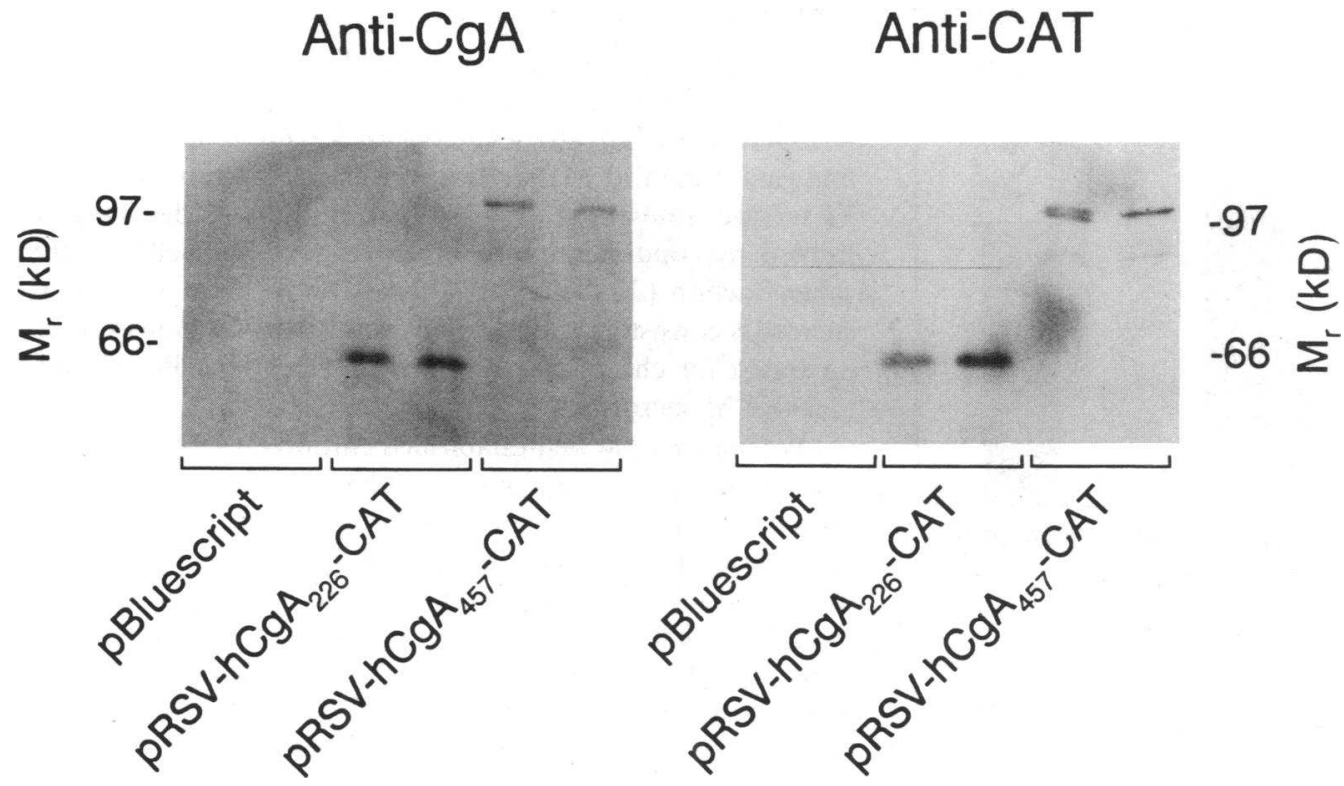

Figure 8. Human $\mathrm{CgA} / \mathrm{CAT}$ fusion studies: Transient expression of human $\mathrm{CgA}$ / CAT fusion proteins in PC12 cells. PC- 12 cells were transiently transfected using the lipofection procedure (31) with $20 \mu \mathrm{g}$ of plasmid DNA (either pRSV-hCgA ${ }_{457}$ CAT [encoding the fulllength human $\mathrm{CgA}$ fused inframe to CAT; lanes 5 and 6], pRSV-hCgA ${ }_{226}$-CAT [encoding the amino-terminal 226 amino acid residues of human $\mathrm{CgA}$ fused in-frame to CAT; lanes 3 and 4], or pBluescript (Stratagene, Inc., La Jolla, CA) as a mock transfection control [lanes 1 and 2]). After 48-60 h, cells were metabolically labeled with $\left[{ }^{35} S\right]$ methionine, washed with PBS and lysed

in $0.1 \mathrm{M} \mathrm{NaCl}, 0.1 \mathrm{M}$ Tris, pH 8.0, $10 \mathrm{mM}$ EDTA, $1 \%$ Triton X-100, $1 \mathrm{mM}$ PMSF, and $50 \mathrm{KIU} / \mathrm{ml}$ aprotinin. Cell lysates were immunoprecipitated with either polyclonal rabbit anti-human $\mathrm{CgA}$ antiserum (left panel) or polyclonal anti-CAT antibody (right panel), and electrophoresed through $8 \%$ SDS-polyacrylamide gels. After fluorographic enhancement, the gels were dried and exposed at $-80^{\circ} \mathrm{C}$ to Kodak X-OMAT AR film for $5 \mathrm{~d}$. Molecular mass standards are indicated. Duplicate lanes represent cell lysates from PC-12 cell plates transfected in duplicate. Expression product of $\mathrm{pRSV}-\mathrm{hCgA} \mathrm{As}_{4}-\mathrm{CAT}$ migrates at $\approx 100-110 \mathrm{kD}$; expression product of $\mathrm{pRSV}$-hCgA ${ }_{226}-\mathrm{CAT}$ migrates at $\approx 60-65 \mathrm{kD}$.

secretagogue-mediated corelease of CAT activity and norepinephrine as an index of targeting into the regulated secretory pathway. Fig. 9 shows results of secretion studies performed in PC-12 cells 48-60 h after transient transfection with pRSVCAT, pRSV-hCgA 457 -CAT, and pRSV-hCgA 226 -CAT. Release of $\left[{ }^{3} \mathrm{H}\right]$ norepinephrine (Fig. 9, lower panel) upon exposure to barium was significant $(P<0.001$, compared with basal values) from cells transfected with all three plasmids and the values did not differ among the three groups. (pBluescript[mock-] transfected cells also released $\left[{ }^{3} \mathrm{H}\right]$ norepinephrine upon exposure to barium to a similar extent [5.3 $\pm 1.0 \%$ to $60.0 \pm 2.0 \%, P<0.001$ ].) Barium released CAT activity (Fig. 9, upper panel) from cells transfected with pRSV-hCgA $\mathrm{A}_{45}-\mathrm{CAT}$ and pRSV-hCgA 226 -CAT $(P<0.001$, compared with the corresponding basal value), but not from cells transfected with pRSV-CAT.

In additional control experiments, we assessed the secretion characteristics of PC-12 cells transfected with pRSV-v-sis $\mathrm{sp}$ CAT, encoding a chimeric protein consisting of the v-sis signal peptide fused in-frame to CAT. Release of $\left[{ }^{3} \mathrm{H}\right]$ norepinephrine in response to $2 \mathrm{mM}$ barium (from $4.7 \pm 0.12 \%$ to $67.6 \pm 0.6 \%, n=$ $8, P<0.001)$ was comparable to cells transfected with the above $\mathrm{CgA} / \mathrm{CAT}$ fusion constructs. Release of CAT activity from these cells did not change in response to barium (from $8.9 \pm 0.20 \%$ to $7.4 \pm 0.5 \%, n=8, P$ not significant).

\section{Discussion}

In studying protein targeting into catecholamine storage vesicles, we focused on $\mathrm{CgA}$ for several reasons: (a) $\mathrm{CgA}$ is the major soluble protein in the core of the catecholamine storage vesicles (7). (b) $\mathrm{CgA}$ itself may be important in the targeting of other secretory proteins to the regulated pathway. Recent evidence suggests that proteins of the chromogranin/secreto- granin ("granin") family may act as linker or adapter molecules involved in the aggregation and packaging of peptide hormones and neuropeptides, facilitating their entry into the regulated secretory pathway (12). (c) CgA may act within the chromaffin granule by binding other nonprotein vesicular constituents including $\mathrm{Ca}^{++}(9,45-47)$, ATP (48), and the catecholamines themselves (47), thereby stabilizing the intragranular complex to allow high concentrations of these compounds. (d) $\mathrm{CgA}$ may play a role in regulation of exocytotic release from the catecholamine storage vesicle. Recent studies have demonstrated that $\mathrm{CgA}$ is the parent molecule for the peptide "chromostatin," a potent inhibitor of catecholamine release from chromaffin cells (14), thereby providing an autocrine/ paracrine neuromodulatory role. $(e)$ As suggested by nuclear magnetic resonance (49) and circular dichroism (50) studies, $\mathrm{CgA}$ exists in solution predominantly in a random coil, extended chain conformation. Thus, one might predict that the virtually structureless nature of $\mathrm{CgA}$ would render this protein less susceptible to tertiary structure disruptions after mutagenesis and gene fusions designed to identify specific targeting domains. This may be an important consideration since some proteins' secretory transport beyond the endoplasmic reticulum can be severely compromised by tertiary structure disruption (51-53). $(f)$ Finally, $\mathrm{CgA}$ is widely distributed in dense core secretory vesicles throughout the neuroendocrine system (8-11). Thus, identifying mechanisms of targeting $\mathrm{CgA}$ to catecholamine storage vesicles might have broad implications for understanding secretory protein trafficking in general.

We transfected human $\mathrm{CgA}$ into rat chromaffin cells, a strategy that takes advantage of the interspecies divergence in amino acid sequence and epitopes of $\mathrm{CgA}(44)$ but still allows investigation of a resident chromaffin cell secretory protein in chromaffin cells. PC-12 cells transfected with the vector pRSVhCgA, but not mock-transfected PC-12 cells, stably expressed 

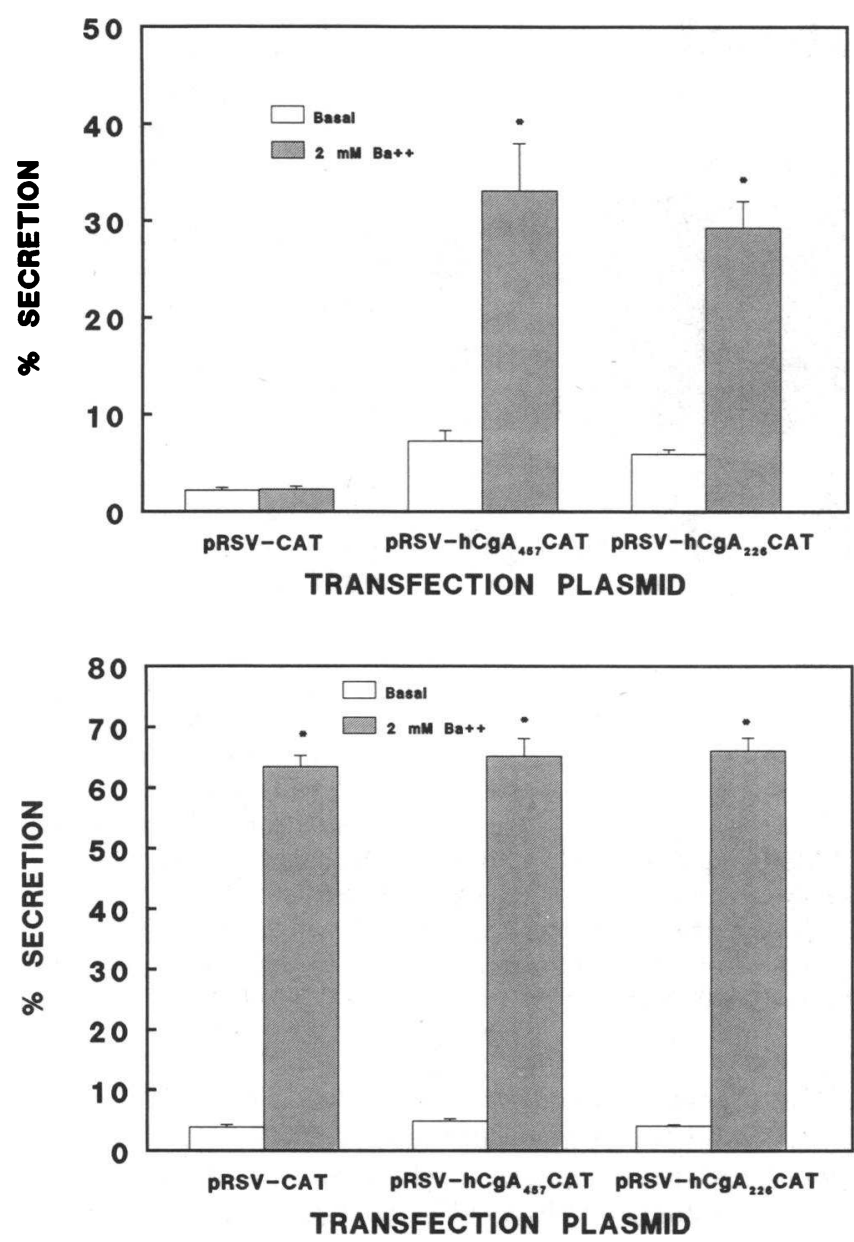

Figure 9. Human $\mathrm{CgA} / \mathrm{CAT}$ fusion studies: secretagogue-stimulated secretion of CAT activity from transfected PC-12 cells. PC- 12 cells transiently transfected with either $\mathrm{pRSV}-\mathrm{hCgA} \mathrm{A}_{47}-\mathrm{CAT}$ (encoding the full-length human $\mathrm{CgA}$ fused in-frame to $\mathrm{CAT}$ ), $\mathrm{pRSV}-\mathrm{hCgA} \mathrm{A}_{226}$-CAT (encoding the amino-terminal 226 amino acid residues of human CgA fused in-frame to CAT), or pRSV-CAT, were labeled with [ $\left.{ }^{3} \mathrm{H}\right]-$ norepinephrine and incubated at room temperature for $30 \mathrm{~min}$ in release buffer ( $150 \mathrm{mM} \mathrm{NaCl}, 5 \mathrm{mM} \mathrm{KCl}, 10 \mathrm{mM}$ Hepes, $\mathrm{pH} \mathrm{7)}$ with or without the secretagogue $\mathrm{BaCl}_{2}$ at $2 \mathrm{mM}$. After aspirating the release buffer, cells were harvested in $150 \mathrm{mM} \mathrm{NaCl}, 5 \mathrm{mM} \mathrm{KCl}, 10$ $\mathrm{mM}$ Hepes, $\mathrm{pH} 7$, and lysed with three freeze-thaw cycles. Release buffer and cell lysate were assayed for CAT activity and $\left[{ }^{3} \mathrm{H}\right]-$ norepinephrine and results expressed as percent secreted: amount in release buffer/total (release buffer + cell lysate). Exposure to barium resulted in significant release of CAT activity (upper panel) from cells transfected with pRSV-hCgA $457-\mathrm{CAT}$ and pRSV-hCgA ${ }_{226}-\mathrm{CAT}\left({ }^{*} P\right.$ $<0.001$, compared with the corresponding basal value), but not from cells transfected with pRSV-CAT. Release of $\left[{ }^{3} \mathrm{H}\right]$ norepinephrine (lower panel) upon exposure to barium was significant $(P<0.001$, compared with basal values) from cells transfected with all three plasmids and the values did not differ among the three groups. (pBluescript-[mock] transfected cells also released $\left[{ }^{3} \mathrm{H}\right]$ norepinephrine to a similar extent (from a basal value of $5.3 \pm 1.0 \%$ to a stimulated value of $60.0 \pm 2.0 \%, P<0.002$ ) upon exposure to barium.) Values are represented as the mean \pm SEM of 6-10 independent transfections for each group.

human $\mathrm{CgA}$. Expression of $\mathrm{CgA}$ was demonstrated in cell lysates of transfected cells by a species-specific human CgA RIA and by Western blotting with a species-specific anti-human CgA antiserum (Fig. 3).
Subcellular localization of the expressed human $\mathrm{CgA}$ was evaluated by both sucrose density gradient studies and secretagogue-mediated release studies.

Sucrose gradient studies colocalized expressed human $\mathrm{CgA}$ and catecholamine to the same subcellular fraction at 1.3-1.4 $M$ sucrose. Interpretation of sucrose gradient studies may be limited by copurification of heterogeneous organelles to the same fraction (24-26). Nonetheless, the peak at 1.3-1.4 M sucrose is consistent with the buoyant density previously demonstrated for chromaffin granules isolated from PC-12 cells (1.2-1.4 M sucrose) $(24,25)$.

We used several well-established chromaffin-cell exocytotic secretagogues to assess the subcellular location of transfected human $\mathrm{CgA}$. Since only proteins correctly targeted to granules are responsive to secretagogue, the extent of secretagogue-induced release relative to basal secretion is a measure of the efficiency at which the protein is targeted to the regulated pathway (54). Stimulation of human CgA-expressing PC-12 cells with the nicotinic agonist carbachol, potassium chloride, or barium chloride all resulted in cosecretion of human $\mathrm{CgA}$ and catecholamines (Figure 6).

In these secretion studies (Figure 6), we found a consistent disparity between the percentage of norepinephrine and the percentage of $\mathrm{CgA}$ released in response to secretagogue, with greater values for norepinephrine release in all cases. We previously demonstrated time-dependent differences between catecholamine release and $\mathrm{CgA}$ release from chromaffin cells (55). At first glance, this may suggest that $\mathrm{CgA}$ and norepinephrine are segregated into separate releasable pools. However, Pimplikar and Huttner (56) recently showed that the chromogranins bind to chromaffin granule membranes in a saturable and specific manner, so that some of the $\mathrm{CgA}$ initially secreted upon stimulation into the release medium may be rapidly bound to the chromaffin cell membrane and therefore not measured in the secreted fraction. Previous studies by Settleman et al. (57) also demonstrated that a fraction of $\mathrm{CgA}$ exists in a membraneassociated form. In addition, release of $\mathrm{CgA}$ after synthesis requires trafficking through the endoplasmic reticulum and Golgi stacks before final localization in the dense core secretory vesicles. Thus, a percentage of the measured total cellular $\mathrm{CgA}$ may still be in route to the secretory vesicle and, therefore, unavailable for exocytotic release. In contrast, since the norepinephrine is supplied to the cells as an exogenous label and does not require synthesis or routing through the endoplasmic reticulum or Golgi, a greater percentage of cell norepinephrine may be immediately available for release in response to secretagogue stimulation. Still another explanation is the existence (in addition to the regulated vesicles containing both norepinephrine and $\mathrm{CgA}$ ) of a population of recycled vesicles (58) which, having already released their $\mathrm{CgA}$, contain only (reloaded) norepinephrine. Nonetheless, secretion studies with a variety of secretagogues (Fig. 6) showed parallel secretion of norepinephrine and $\mathrm{CgA}$ such that each increment in norepinephrine release was associated with a corresponding increase in $\mathrm{CgA}$ release, consistent with colocalization of norepinephrine and $\mathrm{CgA}$ to the same subcellular pool. Colocalization of norepinephrine and transfected $\mathrm{CgA}$ to the same subcellular fraction was also supported by sucrose density gradients (Fig. 5).

Additional characterization of catecholamine and human $\mathrm{CgA}$ targeting to the regulated secretory granules was provided by experiments in which transfected PC- 12 cells were treated with the weak bases chloroquine and ammonium chloride 


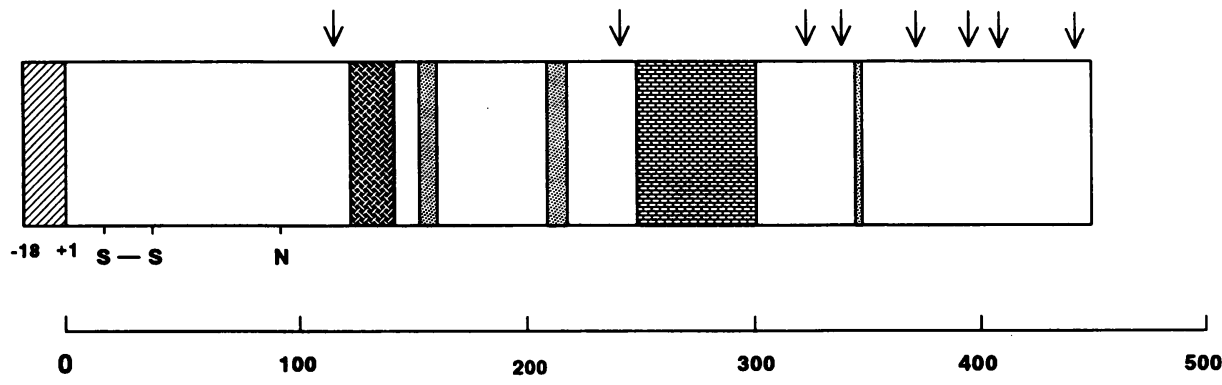

Amino acid residue number

\section{Signal peptide}

\section{Chromostatin}

Pancreastatin

\section{Oligo glu region}

$\downarrow$ Paired basic residues

$\mathrm{N}$ N-glycosylation site
Figure 10. Putative structural domains in human $\mathrm{CgA}$. The amino acid residue number indicated represents the position in the mature protein after signal peptide cleavage. The chromostatin region represents a 20-amino acid peptide sequence homologous to bovine chromostatin (14). Peptide sequence information is from Konecki et al. (40) and Helman et al. (18) as analyzed previously by Parmer et al. (44).

\section{S-S Disulfide loop}

(Fig. 7). Catecholamine storage vesicles and other neurosecretory granules are characterized by the presence of a proton pumping ATPase which maintains an acidic intravesicular $\mathrm{pH}$ $(\mathrm{pH}=5)$ essential for concentration of catecholamines (59). Disruption of the proton gradient by weak bases such as chloroquine and ammonium chloride depletes cells of catecholamines by nonexocytotic catecholamine release, without affecting the intravesicular composition of proteins synthesized and sorted before addition of alkalinizing agent (38). If expressed human $\mathrm{CgA}$ is correctly targeted to the regulated secretory vesicle, then subsequent short-term exposure of PC-12 cells to weak bases would be expected to result in dissociation of release of catecholamines from that of $\mathrm{CgA}$. Both chloroquine and ammonium chloride acutely released norepinephrine but not human $\mathrm{CgA}$ from transfected PC-12 cells (Fig. 7), consistent with such a dissociation, and hence retention of previously sorted $\mathrm{CgA}$ in catecholamine storage vesicles in the face of this nonexocytotic stimulus. Longer exposure to these compounds may divert newly synthesized regulated proteins away from dense core secretory vesicles (60).

We also tested whether human $\mathrm{CgA}$ could divert an ordinarily nonsecreted heterologous protein to the catecholamine storage vesicle. To accomplish this aim, we fused human $\mathrm{CgA}$ in-frame to the bacterial CAT gene. Under normal circumstances, the CAT enzyme is not found in eukaryotic cells. When expression vectors encoding CAT are transfected into mammalian cells, the expressed protein is cytoplasmic, distributed diffusely throughout the cytosol $(30,61-63)$. In our experiments, expressed $\mathrm{CgA} / \mathrm{CAT}$ fusion products were of the appropriate predicted mobility on SDS-PAGE and were immunoprecipitated with both anti-human $\mathrm{CgA}$ and anti-CAT antibodies (Fig. 8), confirming their chimeric structure. We then evaluated the subcellular distribution of these products by assessing corelease of norepinephrine and CAT activity as an index of the secretagogue-dependent releasable pool, i.e., the regulated secretory pathway. In cells transfected with pRSVCAT, exposure to barium did not release CAT activity (Fig. 9), consistent with a cytosolic distribution of expressed CAT (30, 61-63). On the other hand, when $\mathrm{CgA}$ was fused to CAT, a four- to fivefold increment in CAT activity was detected in the release medium after barium (Fig. 9), consistent with targeting of the fusion protein into the regulated secretory pathway. Moreover, fusion of the amino-terminal 226 amino acid residues of human CgA to CAT also caused a four- to fivefold increment in CAT release after barium. Thus, $\mathrm{CgA}$ was capable of diverting CAT into the regulated secretory pathway, and sufficient information for this event is located in CgA's aminoterminal 226 amino acid residues. Of note, the ratio of bariumstimulated to basal release percentages for the chimeric proteins was 4.6 for $\mathrm{hCgA}_{457} \mathrm{CAT}$ and 4.9 for $\mathrm{hCgA}{ }_{226} \mathrm{CAT}$ (Fig. 9, upper panel), compared with a ratio of 16.9 for human $\mathrm{CgA}$ alone (Fig. 6). This suggests that the overall sorting efficiency of the chimeric proteins may have been less than that of human CgA alone.

Although not statistically significant by ANOVA, values for 30-min basal (unstimulated) secretion of CAT activity were slightly greater for cells transiently transfected with pRSV$\operatorname{hCgA}_{457}-\mathrm{CAT}(7.3 \pm 1.1 \%)$ or pRSV-hCgA $226-\mathrm{CAT}(5.9 \pm 0.5 \%)$ compared to cells transfected with pRSV-CAT $(2.2 \pm 0.2 \%)$. Previous studies have suggested that a small percentage of newly synthesized CgA (up to $10 \%$ over a 4-h period) is secreted by the constitutive pathway (64). Since the CgA/CAT fusion proteins had slightly higher basal rates of secretion than the cytoplasmically localized wild-type CAT, a portion of the fusion proteins may have entered the constitutive pathway, or had an increased spontaneous release rate from the regulated pathway (65). Fusion of the v-sis signal peptide sequence to CAT also resulted in slightly greater basal release rates of CAT activity $(8.9 \pm 0.2 \%)$, consistent with entry of the v-sis/CAT chimera into the constitutive pathway, but not into the regu- 
lated pathway, since exposure to barium did not result in further increment of CAT activity in release medium from pRSVv-sis sp $_{\text {CAT-transfected cells. }}$

Results of our CgA/CAT chimera studies are consistent with previous findings on chimeric polypeptides in which fusion of a regulated secretory protein to a heterologous protein resulted in diversion of the latter into the regulated pathway in other secretory cell types (66-69). Using another approach, Rosa et al. (70) introduced (by mRNA injection) antibodies to chromogranin B ( secretogranin I) into PC-12 cells and demonstrated that these antibodies were bound to endogenous chromogranin B and diverted into the regulated pathway. Taken together, these results are consistent with the hypothesis that the targeting of proteins into secretory granules is an active, dominant, signal-mediated process. The trans-Golgi network plays an important role in the process of sorting proteins into the regulated secretory pathway (71-74). Two possible mechanisms have been proposed for targeting into the regulated pathway and for sorting regulated secretory proteins away from constitutive proteins at the trans-Golgi cisternae: $(a)$ receptormediated protein targeting and $(b)$ selective protein aggregation and condensation. In the first mechanism, correct targeting to the regulated pathway results from specific binding to carrier proteins or receptors in the Golgi membrane (75) which recognize sorting signals on targeted proteins. Alternatively, in the second mechanism, sorting of regulated secretory products from other soluble (constitutive) proteins in the pathway results from formation of molecular aggregates triggered by conditions in the trans-Golgi region (acidic $\mathrm{pH}$ and millimolar concentrations of calcium ions) $(12,76)$. Chanat and Huttner (76) demonstrated that selective aggregation of proteins of the chromogranin/secretogranin ("granin") family could be induced by a low $\mathrm{pH}$ and high calcium milieu corresponding to that in the trans-Golgi network lumen. Indeed, this propensity for aggregation was remarkably selective for the granins, suggesting that the granin family may play a crucial role in packaging other polypeptides into the regulated pathway by molecular "hitchhiking" (77) or binding to the aggregated granin complex (12). Since postranslational modification of the chromogranins was not necessary to promote their aggregative properties, the structural features important for aggregation seem to reside in the polypeptide backbone of these proteins (76). Thus, either mechanism (receptor-dependent targeting or selective aggregation ), could be mediated or facilitated by a specific region or regions within the primary structure of $\mathrm{CgA}$. Moreover, our fusion studies suggest that sufficient information for targeting is provided by the amino-terminal portion of CgA.

Previous studies have revealed specific targeting domains for proteins destined for a variety of subcellular locations, including the endoplasmic reticulum (78), Golgi complex (79), lysosomes $(80)$, mitochondria $(81)$, peroxisomes $(61,62)$, and nucleus (82). However, studies to identify targeting signals for sorting to the regulated pathway of secretion have been inconsistent. For example, whereas the pro segment of prosomatostatin may contain important information for targeting to the regulated pathway $(68,69,83)$, mutagenesis studies have thus far failed to reveal discrete, regulated vesicular targeting sequences for a variety of regulated secretory proteins including proinsulin $(54)$, prorenin $(84,85)$, and proparathyroid hormone (86).
What specific domains, particularly within the amino-terminus of $\mathrm{CgA}$, might function in targeting $\mathrm{CgA}$ into dense core secretory granules? Structural features contained in the aminoterminal 226 amino acid residues of $\mathrm{CgA}$ ( that portion of $\mathrm{CgA}$ encoded by $\mathrm{pRSV}-\mathrm{hCgA} \mathrm{A}_{26} \mathrm{CAT}$ ) include the 18-residue amino-terminal signal peptide (residues -18 to -1 ), two cysteine residues (residues +17 and +38 ), a consensus sequence for N-linked glycosylation (NQS, residues +92 to +94 ), a 20 amino acid chromostatin sequence (residues +124 to +143 ) (14), and an oligoglutamic acid cluster (residues +154 to +161 ) (Fig. 10). Of note, $\mathrm{CgA}$ is an extremely hydrophilic protein with the exception of two hydrophobic regions that are well conserved across species. In addition to the 18-residue signal peptide (which is cleaved during cotranslational movement of the protein across the endoplasmic reticulum), a short hydrophobic area occurs near the amino terminus in the region bounded by the two cysteine residues at positions +17 and +38 in the mature protein after signal peptide cleavage (44). These cysteine residues form an intramolecular disulfide loop (87), and the conserved hydrophobic character of this region, given the otherwise quite hydrophilic quality of $\mathrm{CgA}$, has suggested that this domain may interact with Golgi membranes during targeting of $\mathrm{CgA}$ to secretory vesicles (44). Recent analysis of the $\mathrm{CgA}$ gene by our group showed that $\mathrm{CgA}$ 's eight exons correspond in part to putative functional domains suspected within the cDNA-deduced primary structure of the protein (88). It is intriguing that the hydrophobic disulfide loop region is contained within exon 3 (residues +14 to +45$)(88)$, which shares length and partial sequence homology with the disulfide loop-encoding (87) exon 3 of chromogranin B (88), suggesting a conserved structure-function relationship for this region. (Chromogranin B is also efficiently targeted to the catecholamine storage vesicles in chromaffin cells $[12,56,70,76]$.) Alternatively, several oligoglutamic acid regions are present within the primary structure of $\mathrm{CgA}$. These areas contribute to the acidic nature of the protein and may interact with calcium ions and other cations $[9,45-47,50,76]$ in a process which could selectively aggregate $\mathrm{CgA}$ under conditions provided by the trans-Golgi milieu (76). Interestingly, one of the longest of these oligoglutamic acid regions (eight consecutive glutamic acid residues) is present in human $\mathrm{CgA}$ at residues +154 to +161 and is thus included in the protein chimera expressed by transfection with the plasmid pRSV-hCgA $226-\mathrm{CAT}$.

Further mutagenesis studies are in progress to determine whether these hydrophobic or acidic regions or other specific regions within $\mathrm{CgA}$ provide important targeting information, or whether some other, perhaps overall property of $\mathrm{CgA}$ (e.g., its acidic pI ) is important for efficient targeting to the regulated pathway of secretion.

In summary, these studies demonstrate that human $\mathrm{CgA}$ expressed in PC- 12 cells is targeted to the catecholamine storage vesicles. In addition, human $\mathrm{CgA}$ is capable of diverting a heterologous, ordinarily nonsecreted cytoplasmic protein into the regulated pathway of secretion. The amino-terminal half of $\mathrm{CgA}$ contains information sufficient for this event.

\section{Acknowledgments}

We wish to thank Dr. Daniel T. O'Connor for his helpful discussions and advice and for his critical review of the manuscript. We also thank Drs. Suresh Subramani and Daniel Donoghue of UCSD for their help- 
ful discussions and for providing the plasmid vectors, pRSV-L (Dr. Subramani), and pDD-184 (Dr. Donoghue).

This work was supported by the Department of Veterans Affairs, the National Institutes of Health (HL-50174), and the American Heart Association.

\section{References}

1. Kelly, R. B. 1985. Pathways of protein secretion in eukaryotes. Science (Wash. DC). 230:25-32.

2. Moore, H. P. 1987. Factors controlling packaging of peptide hormones into secretory granules. Ann. N. Y. Acad. Sci. 493:50-61.

3. Winkler, H., and E. Westhead. 1980. The molecular organization of adrenal chromaffin granules. Neuroscience. 5:1803-1823.

4. Winkler, H. 1976. The compostion of adrenal chromaffin granules: an assessment of controversial results. Neuroscience. 1:65-80.

5. Parmer, R. J., and D. T. O'Connor. 1988. Enkephalins in human phaeochromocytomas: localization in immunoreactive, high molecular weight form to the soluble core of chromaffin granules. J. Hypertens. 6:187-198.

6. Winkler, H., D. K. Apps, and R. F. Fischer-Colbrie. 1986. The molecular function of adrenal chromaffin granules: established facts and unresolved topics. Neuroscience. 18:261-290.

7. O'Connor, D. T., R. P. Frigon, and R. L. Sokoloff. 1984. Human chromogranin A. Purification and characterization from catecholamine storage vesicles of human pheochromocytoma. Hypertension. 6:2-12.

8. O’Connor, D. T., D. Burton, and L. J. Deftos. 1983. Immunoreactive human chromogranin A in diverse polypeptide hormone producing human tumors and normal endocrine tissues. J. Clin. Endocrinol. Metab. 57:1084-1086.

9. O'Connor, D. T., R. J. Parmer, and L. J. Deftos. 1984. Chromogranin A: studies in the endocrine system. Trans. Assoc. Am. Physicians. 97:242-250.

10. Wilson, B. S., and R. V. Lloyd. 1984. Detection of chromogranin in neuroendocrine cells with a monoclonal antibody. Am. J. Pathol. 115:458-468.

11. Cohn, D. V., J. J. Elting, M. Frick, and R. Elde. 1984. Selective localization of the parathyroid secretory protein I-/adrenal medulla chromogranin A protein family in a wide variety of endocrine cells of the rat. Endocrinology. 114:1963-1974.

12. Huttner, W. B., H. H. Gerdes, and P. Rosa. 1991. The granin (chromogranin/secretogranin) family. Trends. Biochem. Sci. 16:27-30.

13. Tatemoto, K., S. Efendic, V. Mutt, G. Makk, G. J. Feistner, and J. D. Barchas. 1986. Pancreastatin, a novel pancreatic peptide that inhibits insulin secretion. Nature (Lond.). 324:476-478.

14. Galindo, E., A. Rill, M.-F. Bader, and D. Aunis. 1991. Chromostatin, a 20 amino acid peptide derived from chromogranin A, inhibits chromaffin cell secretion. Proc. Natl. Acad. Sci. USA. 88:1426-1430.

15. Greene, L. A., and A. S. Tischler. 1976. Establishment of a noradrenergic clonal cell line of rat adrenal pheochromocytoma cells which respond to nerve growth factor. Proc. Natl. Acad. Sci. USA. 73:2424-2428.

16. Schweitzer, E. S., and R. B. Kelly. 1985. Selective packaging of human growth hormone into synaptic vesicles in a rat neuronal (PC12) cell line. J. Cell Biol. 101:667-676.

17. Schweitzer, E. S., and S. Paddock. 1990. Localization of human growth hormone to a sub-set of cytoplasmic vesicles in transfected PC12 cells. J. Cell Sci. 96:375-381.

18. Helman, L. J., T. G. Ahn, M. A. Levine, A. Allison, P. S. Cohen, M. J. Cooper, D. V. Cohn, and M. A. Israel. 1988. Molecular cloning and primary structure of human chromogranin A (secretory protein I) cDNA. J. Biol. Chem. 263:11559-11563.

19. de Wet, J. R., K. V. Wood, M. DeLuca, D. R. Helinski, and S. Subramani. 1987. Firefly luciferase gene: structure and expression in mammalian cells. $\mathrm{Mol}$. Cell. Biol. 7:725-737.

20. Gorman, C. M. 1985. High efficiency gene transfer into mammalian cells. In DNA Cloning: A Practical Approach. Volume II. D. M. Glover, editor. IRL Press, Ltd., Oxford, UK. 143-190.

21. Southern, P. J., and P. Berg. 1982. Transformation of mammalian cells to antibiotic resistance with a bacterial gene under control of the SV40 early region promoter. J. Mol. Appl. Genet. 1:327-341.

22. O'Connor, D. T., M. R. Pandlan, E. Carlton, J. H. Cervenka, and R. J. Hsiao. 1989. Rapid radioimmunoassay of circulating chromogranin A: in vitro stability, exploration of the neuroendocrine character of neoplasia, and assessment of the effects of organ failure. Clin. Chem. 35:1631-1637.

23. Smith, A. D., and H. Winkler. 1967. A simple method for the isolation of adrenal chromaffin granules on a large scale. Biochem. J. 103:480-482.

24. Schubert, D., and F. G. Klier. 1977. Storage and release of acetylcholine by a clonal cell line. Proc. Natl. Acad. Sci. USA. 74:5184-5188.

25. Roda, L. G., J. A. Nolan, S. U. Kim, and R. A. Hogue-Angeletti. 1980. Isolation and characterization of chromaffin granules from a pheochromocytoma (PC12) cell line. Exp. Cell. Res. 128:103-109.
26. Oberlechner, E., E. Westhead, B. Neuman, W. Schmidt, R. Fischer-Colbrie, A. Weber, G. Sperk, and H. Winkler. 1982. Characterization of catecholamine-storage organelles in transplantable phaeochromocytoma and adrenal glands of rats. J. Neurochem. 38:615-624.

27. Bradford, M. M. 1976. A rapid and sensitive method for the quantitation of microgram quantities of protein using the principle of protein dye binding. Anal. Biochem. 72:248-254.

28. Innis, M. A., and D. H. Gelfand. 1990. Optimization of PCRs. In PCR Protocols, A Guide to Methods and Applications. M. A. Innis, D. H. Gelfand, J. J. Sninsky, and T. J. White, editors. Academic Press, Inc., San Diego, CA. 3-12.

29. Mattila, P., J. Korpela, T. Tenkanen, and K. Pitkanen. 1991. Fidelity of DNA synthesis by the Thermococcus litoralis DNA polymerase-an extremely heat stable enzyme with proofreading activity. Nucleic. Acids. Res. 19:49674973.

30. Gorman, C. M., G. T. Merlino, M. C. Willingham, I. Pastan, and B. H. Howard. 1982. The Rous sarcoma virus long terminal repeat is a strong promoter when introduced into a variety of eukaryotic cells by DNA-mediated transfection. Proc. Natl. Acad. Sci. USA. 79:6777-6781.

31. Felgner, P. L., T. R. Gadek, M. Holm, R. Roman, H. W. Chan, M. Wenz, J. P. Northrop, G. M. Ringold, and M. Danielsen. 1987. Lipofection: a highly efficient, lipid-mediated DNA-transfection procedure. Proc. Natl. Acad. Sci. USA. 84:7413-7417.

32. Muller, S. R., P. D. Sullivan, D. O. Clegg, and S. C. Feinstein. 1990. Efficient transfection and expression of heterologous genes in PC12 cells. DNA Cell Biol. 9:221-229.

33. Sambrook, J., E. F. Fritsch, and T. Maniatis. 1989. Molecular Cloning, A Laboratory Manual. Cold Spring Harbor Laboratory Press, Cold Spring Harbor, NY. 16.63-16.64.

34. Sauer, M. K., M. Hannink, and D. J. Donoghue. 1986. Deletions in the $\mathrm{N}$-terminal coding region of the v-sis gene: determination of the minimal transforming region. J. Virol. 59:292-300.

35. Hannink, M., and D. J. Donoghue. 1986. Biosynthesis of the v-sis gene product: signal sequence cleavage, glycosylation, and proteolytic processing. $\mathrm{Mol}$. Cell. Biol. 6:1343-1348.

36. Hannink, M., and D. J. Donoghue. 1984. Requirement for a signal sequence in biological expression of the v-sis oncogene. Science (Wash. DC). 226:1197-1199.

37. Zar, J. H. 1984. Biostatistical Analysis. Prentice-Hall, Inc., Englewood Cliffs, NJ. 190.

38. Sabban, E. L., J. Schwartz, and A. McMahon. 1990. Effect of compounds which disrupt proton gradients on secretion of neurosecretory proteins from PC1 2 pheochromocytoma cells. Neuroscience. 38:561-570.

39. Laredo, J., V. L. Wolff, and P. S. Lovett. 1988. Chloramphenicol acetyltransferase specified by cat-86: relationship between the gene and the protein. Gene. 73:209-214.

40. Konecki, D. S., U. M. Benedum, H. H. Gerdes, and W. B. Huttner. 1987. The primary structure of human chromogranin A and pancreastatin. J. Biol. Chem. 262:17026-17030.

41. Benedum, U. M., P. A. Baeuerle, D. S. Konecki, R. Frank, J. Powell, J. Mallet, and W. B. Huttner. 1986. The primary structure of bovine chomogranin A: a representative of a class of acidic secretory proteins common to a variety of peptidergic cells. EMBO (Eur. Mol. Biol. Organ.) J. 5:1495-1502.

42. Iacangelo, A., H-U. Affolter, L. E. Eiden, E. Herbert, and M. Grimes. 1986. Bovine chromogranin A sequence and distribution of its messenger RNA in endocrine tissues. Nature (Lond.). 323:82-86.

43. Simon, J.-P., and D. Aunis. 1989. Biochemistry of the chromogranin A protein family. Biochem. J. 262:1-13.

44. Parmer, R. J., A. H. Koop, M. T. Handa, and D. T. O’Connor. 1989. Molecular cloning of chromogranin A from rat pheochromocytoma cells. Hypertension. 14:435-444.

45. Reiffen, F. U., and M. Gratzl. 1986. $\mathrm{Ca}^{++}$binding to chromaffin vesicle matrix proteins: effect of $\mathrm{pH}, \mathrm{Mg}^{++}$, and ionic strength. Biochemistry. 25:44024406.

46. Reiffen, F. U., and M. Gratzl. 1986. Chromogranins, widespread in endocrine and nervous tissue, bind $\mathrm{Ca}^{++}$. FEBS (Fed. Eur. Biochem. Soc.) Lett. 195:327-330.

47. Videen, J. S., M. S. Mezger, Y-M. Chang, and D. T. O’Connor. 1992. Calcium and catecholamine interactions with adrenal chromogranins: comparison of driving forces in binding and aggregation. J. Biol. Chem. 267:3066-3073.

48. Daniele, A. J., R. J. P. Williams, and P. E. Wright. 1978. The character of the stored molecules in chromaffin granules of the adrenal medulla: a nuclear magnetic resonance study. Neuroscience. 3:573-585.

49. Weiland, G. A., K. P. Minneman, and P. B. Molinoff. 1980. Thermodynamics of agonist and antagonist interactions with mammalian beta-adrenergic receptors. Mol. Pharmacol. 18:341-347.

50. Yoo, S. H., and J. P. Albanesi. 1990. Ca2(+)-induced conformational change and aggregation of chromogranin A. J. Biol. Chem. 265:14414-14421.

51. Gething, M.-J. K., K. McCammon, and J. Sambrook. 1986. Expression of 
wild type and mutant forms of influenza hemagglutinin: the role of folding in intracellular transport. Cell. 46:939-950.

52. Kreis, T. E., and H. F. Lodish. 1986. Oligomerization is essential for transport of vesicular stomatitis viral glycoprotein to the cell surface. Cell. 46:929-937.

53. Tartakoff, A. M. 1983. Mutations that influence the secretory path in animal cells. Biochem. J. 216:1-9.

54. Powell, S. K., L. Orci, C. S. Craik, and H. P. Moore. 1988. Efficient targeting to storage granules of human proinsulins with altered propeptide domain. J. Cell Biol. 106:1843-1851.

55. Takiyyuddin, M. A., J. H. Cervenka, P. A. Sullivan, M. R. Pandian, R. J. Parmer, J. A. Barbosa, and D. T. O'Connor. 1990. Is physiologic sympathoadrenal catecholamine release exocytotic in humans. Circulation. 81:185-195.

56. Pimplikar, S. W., and W. B. Huttner. 1992. Chromogranin B (secretogranin I), a secretory protein of the regulated pathway, is also present in a tightly membrane-associated form in PC12 cells. J. Biol. Chem. 267:4110-4118.

57. Settleman, J., J. Nolan, and R. H. Angeletti. 1985. Chromogranin, an integral membrane protein. J. Biol. Chem. 260:1641-1644.

58. Patzak, A., and H. Winkler. 1986. Exocytotic exposure and recycling of membrane antigens of chromaffin granules: ultrastructural evaluation after immunolabeling. J. Cell Biol. 102:510-515.

59. Johnson, R. G. 1988. Accumulation of biological amines into chromaffin granules: a model for hormone and neurotransmitter transport. Physiol. Rev. 68:232-307.

60. Moore, H. P., B. Gumbiner, and R. B. Kelly. 1983. Chloroquine diverts ACTH from a regulated to a constitutive secretory pathway in AtT-20 cells. Nature (Lond.). 302:434-436.

61. Gould, S. J., G.-A. Keller, and S. Subramani. 1987. Identification of a peroxsisomal targeting signal at the carboxy terminus of firefly luciferase. J. Cell Biol. 105:2923-2391.

62. Gould, S. J., G.-A. Keller, and S. Subramani. 1988. Identification of peroxisomal targeting signals located at the carboxy terminus of four peroxisoma proteins. J. Cell Biol. 107:897-905.

63. Holt, C. E., N. Garlick, and E. Cornel. 1990. Lipofection of cDNAs in the embryonic vertebrate central nervous system. Neuron. 4:203-214.

64. Corcoran, J. J., and N. Kirshner. 1990. Synthesis of chromogranin A, dopamine beta-hydroxylase, and chromaffin vesicles. Am. J. Physiol. 259:C161C168.

65. Matsuuchi, L., and R. B. Kelly. 1991. Constitutive and basal secretion from the endocrine cell line, AtT-20. J. Cell Biol. 112:843-852.

66. Seethaler, G., M. Chaminade, R. Vlasak, M. Ericsson, G. Griffiths, O. Toffoletto, J. Rossier, H. G. Stunnenberg, and G. Kreil. 1991. Targeting of frog prodermorphin to the regulated secretory pathway by fusion to proenkephalin. $J$. Cell Biol. 114:1125-1133.

67. Moore, H-P. H., and R. B. Kelly. 1986. Re-routing of a secretory protein by fusion with human growth hormone sequences. Nature (Lond.). 321:443-446.

68. Sevarino, K. A., P. Stork, R. Ventimiglia, G. Mandel, and R. H. Goodman. 1989. Amino-terminal sequences of prosomatostatin direct intracellular targeting but not processing specificity. Cell. 57:11-19.

69. Stoller, T. J., and D. Shields. 1989. The propeptide of preprosomatostatin mediates intracellular transport and secretion of alpha-globin from mammalian cells. J. Cell Biol. 108:1647-1655.
70. Rosa, P., U. Weiss, R. Pepperkok, W. Ansorge, C. Niehrs, E. H. Stelzer, and W. B. Huttner. 1989. An antibody against secretogranin I (chromogranin B) is packaged into secretory granules. J. Cell Biol. 109:17-34.

71. Farquhar, M. G., and G. E. Palade. 1981. The Golgi apparatus (complex)(1954-1981)-from artifact to center stage. J. Cell Biol. 91:77s-103s.

72. Tooze, S. A., and W. B. Huttner. 1990. Cell-free protein sorting to the regulated and constitutive secretory pathways. Cell. 60:837-847.

73. Orci, L., M. Ravazzola, M. Amherdt, A. Perrelet, S. K. Powell, D. L. Quinn, and H. P. Moore. 1987. The trans-most cisternae of the Golgi complex: a compartment for sorting of secretory and plasma membrane proteins. Cell. 51:1039-1051.

74. Sossin, W. S., J. M. Fisher, and R. H. Scheller. 1990. Sorting within the regulated secretory pathway occurs in the trans-Golgi network. J. Cell Biol. 110:1-12.

75. Chung, K. N., P. Walter, G. W. Aponte, and H. P. Moore. 1989. Molecular sorting in the secretory pathway. Science (Wash. DC). 243:192-197.

76. Chanat, E., and W. B. Huttner. 1991. Milieu-induced, selective aggregation of regulated secretory proteins in the trans-Golgi network. J. Cell Biol. 115:1505-1519.

77. Brion, C., S. G. Miller, and H. P. Moore. 1992. Regulated and constitutive secretion. Differential effects of protein synthesis arrest on transport of glycosaminoglycan chains to the two secretory pathways. J. Biol. Chem. 267:1477-1483.

78. Rothman, J. E. 1987. Protein sorting by selective retention in the endoplasmic reticulum and Golgi stack. Cell. 50:521-522.

79. Machamer, C. E., and J. K. Rose. 1987. A specific transmembrane domain of a coronavirus E1 glycoprotein is required for its retention in the Golgi region. J. Cell Biol. 105:1205-1214.

80. Farquhar, M. G. 1985. Progress in unraveling pathways of Golgi traffic. Annu. Rev. Cell Biol. 1:447-488.

81. Schatz, G. 1987. Signals guiding proteins to their correct locations in mitochondria. Eur. J. Biochem. 98:1-6.

82. Kalderon, D., B. L. Roberts, W. D. Richardson, and A. E. Smith. 1984. A short amino acid sequence able to specify nuclear location. Cell. 39:499-509.

83. Sevarino, K. A., and P. Stork. 1991. Multiple preprosomatostatin sorting signals mediate secretion via discrete cAMP- and tetradecanoylphorbolacetateresponsive pathways. J. Biol. Chem. 266:18507-18513.

84. Chu, W. N., J. D. Baxter, and T. L. Reudelhuber. 1990. A targeting sequence for dense secretory granules resides in the active renin protein moiety of human preprorenin. Mol. Endocrinol. 4:1905-1913.

85. Chidgey, M. A., and T. M. Harrison. 1990. Renin is sorted to the regulated secretory pathway in transfected PC12 cells by a mechanism which does not require expression of the pro-peptide. Eur. J. Biochem. 190:139-144.

86. Wiren, K. M., J. T. Potts, Jr., and H. M. Kronenberg. 1988. Importance of the propeptide sequence of human preproparathyroid hormone for signal sequence function. J. Biol. Chem. 263:19771-19777.

87. Benedum, U. M., A. Lamouroux, D. S. Konecki, P. Rosa, A. Hille, P. A. Baeuerle, R. Frank, F. Lottspeich, J. Mallet, and W. B. Huttner. 1987. The primary structure of human secretogranin I (chromogranin B): comparison with chromogranin A reveals homologous terminal domains and a large intervening variable region. EMBO (Eur. Mol. Biol. Organ.) J. 6:1203-1211.

88. Wu, H. J., D. J. Rozansky, R. J. Parmer, B. M. Gill, and D. T. O'Connor. 1991. Structure and function of the chromogranin A gene: Clues to evolution and tissue-specific expression. J. Biol. Chem. 266:13130-13134. 